\title{
XVIII. Yüzyılın Illk Yarısında Kuban Boyunda Siyaset, Etnik Yapı ve İktisat
}

İsmail Bülbül*

\section{Özet}

Kuban Boyu, Kuzey Kafkasya'nın batısındaki bölgedir. Bu bölge etnik çeşitlilik açısından Kafkasların diğer bölgelerinden pek farklı değildir. Bölgeyi idare edenler bu etnik çeşitliliği dikkate alarak farklı politikalar geliştirmek zorunda kalmışlardır. Siyasal yaşamdaki bu farklılığa karşılık iktisadi hayatta bir bütünlük söz konusudur. Bu bütünlüğü sağlayan büyük ölçüde coğrafi etkenler gibi görünmektedir.

$\mathrm{Bu}$ çalışmada, Başbakanlık Osmanlı Arşivinde yer alan Mühimme Defterleri'nden, dönemin kroniklerinden ve seyyahlarından hareketle XVIII. yüzyılın ilk yarısında Kuban Boyundaki siyasal yaşam, etnik yapı ve iktisadi faaliyetler ele alınmıştır.

Anahtar Kelimeler: Kuban Nehri, Çerkezler, Nogaylar, Kırım Hanlığı, Osmanlı Devleti

\section{Politics, Ethnicity and Economics within the Kuban Tribe in the first half of the XVIIIth century}

\section{Abstract}

The Kuban Region is the West part of the Northern Caucasus. In terms of ethnic diversity, The Kuban Region does not differ from other parts of the Caucasus. Authorities those who govern The Kuban Region have had to develop various policies in accordance with the ethnic diversity of The Kuban Region. In contrast to ethnic differences within the political sphere, sociocultural and economic spheres are unified. It is seen that geographical aspects have positive impacts on the unity which is observed in socio-cultural and economic life.

These paper discuses that political life, ethnicity and economic activities of the people of The Kuban Region in the XVIIIth century bt docusing on the

\footnotetext{
* Yrd. Doç. Dr., Mustafa Kemal Üniversitesi, Fen-Edebiyat Fakültesi, Tarih Bölümü, ibulbul@mku.edu.tr. (ORCID ID: 0000-0002-7111-4537)
}

(Makale Gönderim Tarihi: 12.06.2017, Makale Kabul Tarihi: 09.08.2017)

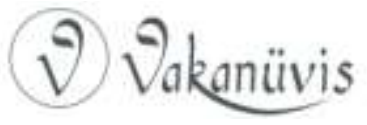


Muhimme Records in the Ottoman Archives, annals and diaries of the travellers.

Keywords: Kuban River, Circassians, Nogais, Crimean Khanate, Ottoman Empire

\section{Giriş}

Kuzey Kafkasya'nın batısında bulunan Kuban Boyu, XV. yüzyılın ortalarında Kırım Hanlığının egemenliği altına girmiştir. XV. yüzyıl sona ererken bölge Osmanlı Devletinin bir parçası olmuştur. Bu dönemden itibaren bölgede Kırım Hanlığı ile Osmanlı Devleti'nin ortaklaşa yönetimi söz konusudur. Öte yandan Rusya'nın XVI. yüzyıldan itibaren bölgeyi ele geçirmeye yönelik bir politika takip ettiği görülmektedir. Rusların bu yayılmacı politikasının bölgenin etnik haritasının şekillenmesinde tesiri vardır. Bununla birlikte bu haritaya Osmanlı Devleti'nin ve Kırım Hanlığının bölgeye yönelik politikaları dikkate alınarak bakılmalıdır. Buna ilaveten bu devletlerin politikalarını daha iyi anlayabilmek ve etnik gruplar arasındaki ilişkilerin boyutunu çözümleyebilmek için bölgenin ekonomisine de göz atmak gerekir. Çünkü politikaların belirlenmesinde ve ilişkilerin seyrinde iktisadi faaliyetlerin mühim bir rolü bulunmaktadır.

Kırım Hanlığı ya da Kafkasya'ya dair çalışmalarda Kuban Boyuyla ilişkili anlatımlar bulunmaktadır. Ancak müstakil olarak Kuban Boyunu ele alan bir çalışma bulunmamaktadır. Bu çalışmada XVIII. yüzyılın ilk yarısında Kuban Boyundaki siyasi yaşam, etnik yapı ve iktisadi faaliyetler ele alınmıştır. Başbakanlık Osmanlı Arşivinde yer alan Mühimme Defterleri ve Nâme-i Hümâyûn Defterleri, Osmanlı tarihleri ve dönemin seyyahlarının anlatımları bu çalışmanın ana kaynaklarıdır.

\section{Kuban Boyunun Coğrafyası}

Kuban Boyunun güneyi Kafkas sıradağları, batısı Karadeniz ve Azak Denizi, kuzeyi Ten Nehri havzası, doğusu ise Terek Nehri havzası ile çevrilidir (Bkz. EK-1). Bölgenin adı, bölgenin ortasından akan Kuban Nehri'nden gelmektedir. Kuban Nehri, Kafkas Dağlarının zirvesi olan Elbruz Dağı'ndan doğar ve yine kaynağı Kafkas Dağları'nda olan çeşitli nehirlerle beslenerek batıya doğru akar. Nehir, Taman Yarımadası'nın yakınlarında iki kola ayrılır. Bir kol Karadeniz'e, diğer kol ise yine ikiye

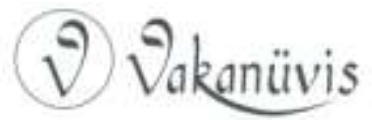


ayrılarak Azak Denizi'ne dökülür. Nehrin ve onu besleyen kolların yukarı kısımlarında sular şiddetli aktığından buralarda derin vadiler meydana gelmiştir. Buna karşılık nehrin aşağı kısımlarında akıntı yavaşlar ve nehir sivrisinek ve karasineklere ev sahipliği yapan çok sayıda göl, sazlık, bataklık ve kumlu alan oluşturur. Bataklıklardan yayılan zehirli gazlar yaşam koşullarını zorlaştırır. ${ }^{1}$ Kuban Nehri'nde ilkbahar ve yaz aylarında karların erimesiyle, son bahar ayında yağmurların etkisiyle yılda ortalama 6-7 defa taşkın meydana gelir. Bu durum su seviyesinde yaklaşık 5 metrelik bir farkın doğmasına yol açar ve nehrin etrafı sel suları altında kalır. ${ }^{2}$

Kuban Nehri'nin kuzeyi, Deşt-i Kıpçak bozkırının tipik özelliğine sahiptir: Bahar ayında yeşeren otlar ve çalılıklar yaz ayında sararmaya yüz tutar. Toprak boz renkli bir çöl görüntüsüne bürünür. Hayvanların otlatılabileceği meralara azalır. Bu otlaklar da zaman zaman çekirge istilaları ile tahrip olur. Kış aylarında ise Sibirya'nın sert rüzgarları bölgeye ulaşarak korkunç fırtınalara ve şiddetli soğuklara neden olur. ${ }^{3}$

Kuban Nehri'nin güneyi, kuzeyinin tam zıttı olan bir yapı arz eder. Burada düzlükler yerini engebeli arazilere bırakmaya başlar. Kuzeyin kesintisiz bozkırına karşılık güney bölgesi Kuban Nehrini besleyen irili ufaklı çok sayıda nehir tarafından parçalara ayrılır. Bu parçalanmış coğrafyanın en belirgin özelliği sık ormanlara sahip olmasıdır. Burada her türden ağaca rastlamak mümkündür. Ayrıca bölge, orman altı bitki örtüsü açısından da zengindir. Yüksek kesimlerde Kafkaslara özgü çeşitli çiçekler vardır. Bu çiçekler ballara baharat tadı katar ve içlerinden yaban gülü denilen bir tür çiçek bala sarhoş edici bir özellik vermesiyle tanınır. Bitki örtüsünde görülen çeşitlilik yaban hayatı için

\footnotetext{
${ }^{1}$ Sergey Enisimof, Kafkas Kılavuzu, Çev. Binbaşı Sadık, İstanbul 1926, s. 55, 56; Edmund Spencer, Türkiye, Rusya, Karadeniz ve Çerkezistan, Çev. Dilek Cenkçiler, Ankara 2014, s. 259; Malte Brun, Universal Geography or a Description of all the Parts of the World, V. II, Boston 1824, s. 43.

2 Yakup Basmacı, "Kafkasya Bölgesi Su Kaynakları”, Yeni Türkiye (Kafkaslar Özel Sayısı), S. 71, C. I, 2015, s. 336; Enisimof, a.g.e., s. 54; Edmund Spencer, a.g.e., s. 259; HansJürgen Kornrumpf, "Südrussland und die Krım um 1740", Osmanlı Araştırmaları IX, İstanbul 1989, s. 251.

${ }^{3}$ Moritz Wagner, Kafkas Rus Savaşı'nda Çerkesler-Çeçenler-Kazaklar ve Gürcüler, Çev. Sedat Özden, İstanbul 1999, s. 197; Enisimof, a.g.e., s. 57; Edmund Spencer, a.g.e., s. 247.
} 
de geçerlidir. Ormanlarda sayısız av hayvanı, nehirlerde ise türlü balıklar bulunur. ${ }^{4}$

\section{Siyaset}

Kuban Boyunun hem Osmanlı Devleti'nin hem de Kırım Hanlığının idaresinde olması, bölgede farklı etnik grupların bulunması ve Rusların bölgeyi ele geçirmeye yönelik politikası Kuban Boyundaki siyasi hayatın anlaşılmasını güçleştirmektedir. Bu zorluğu aşabilmek için konu beş başlık altında incelenmiştir.

\section{Kırım Hanlığının Çerkezlerle Olan İlişkileri}

Çerkezler, Kırım Hanlığının kurucusu olan Hacı Giray zamanında hanlığın idaresi altına girmişlerdir. ${ }^{5}$ Hanlığın Çerkezlere yönelik politikası da muhtemelen bu dönemde belirlenmiş olmalıdır. $\mathrm{Bu}$ politika Çerkezlerin hanlığa itaat etmelerini esas alan bir temele dayanmaktadır. Bu politika çerçevesinde Çerkezler itaatlerinin göstergesi olarak hanlığa yıllık vergi ve istendiğinde asker göndermişler, buna karşılık iç işlerinde serbest kalmışlardır. Ayrıca Çerkezlerin han değişikliğinde yeni hana kıymetli hediyeler sunması da bir gelenek haline gelmiştir. ${ }^{6}$ Kırım Hanlığı, bu siyasi anlaşmayı atalık müessesesi ile kalıcı hale getirmiştir. Burada, yeni doğan han çocuğunun yetiştirilmek üzere bir Çerkez ailesine verilmesi söz konusudur. Böylelikle Kırım hanları ile Çerkezler arasında kan bağına dayanmayan bir tür akrabalık kurulmuş ve Çerkezlerin hanlık ile olan bağları güçlendirilmiştir. ${ }^{7}$ Bununla birlikte zaman zaman siyasi ve

\footnotetext{
${ }^{4}$ Edmund Spencer, a.g.e., s. 338, 339, 341; Malte Brun, a.g.e., s. 31, 47; Jean-Baptiste Tavernier, Tavernier Seyahatnamesi, Çev. Teoman Tunçdoğan, İstanbul 2006, s. 313.

${ }^{5}$ Akdes Nimet Kurat, Altın Ordu, Kırım ve Türkistan Hanlarına Ait Yarlık ve Bitikler, İstanbul 1940, s. 62, 77.

${ }^{6}$ Hezarfen Hüseyin Efendi, Telhîsü'l-Beyân Fî Kavânîn-i Âli-i Osman, Haz. Sevim İlgürel, Ankara 1998, s. 172; A. De La Motraye, A. De La Motraye's Travels through Europe, Asia and into Part of Africa, V. II, London 1730, s. 34, 76; Silâhdar Fındıklılı Mehmed Ağa, Nusretnâme, Sadeleştiren İsmet Parmaksızoğlu, C. II/II, İstanbul 1969, s. 247.

${ }^{7}$ Hezarfen Hüseyin Efendi, a.g.e., s. 172; Mustafa Kesbî, ibretnümâ-yı Devlet, Haz. Ahmet Öğreten, Ankara 2002, s. 11; Ufuk Tavkul, "Kırım-Kafkasya Illişkilerinde 'Atalık' Kurumunun Kökeni Üzerine Değerlendirmeler", Karadeniz Araştırmaları, Sayı 51, 2016, s. 224-225, 229; Derya Derin Paşaoğlu, "Altın Orda ve Kırım Sahasında Bozkır Aristokrasisinin Güçlü Temsilcileri: Emir Rektemür ve Şirin Mirzalar", Ankara Üniversitesi Dil ve Tarih-Coğrafya Fakültesi Tarih Bölümü Tarih Araştırmaları Dergisi, C.
}

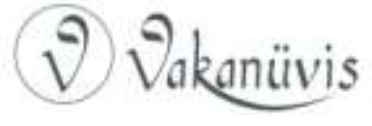


iktisadi sebeplerden dolayı Çerkezlerin hanlığa olan bağlılıkları zayıflamaktadır.

Osmanlı Devleti XVII. yüzyılın ikinci yarısında Batı dünyası ile giriştiği mücadeleyi kaybetmiş, bunun sonucunda devletin siyasi itibarı zedelenmiş ve ekonomisi ciddi bir sarsıntı geçirmiştir. Bu siyasi ve iktisadi bunalım Kırım Hanlığını derinden etkilemiştir. Çerkezler, hanlığın otoritesinin zayıflamasını fırsat bilerek itaatten yüz çevirmişlerdir. ${ }^{8}$ II. Devlet Giray ${ }^{9}$, Çerkezleri yeniden itaat altına almak için 1701 yılında kardeşi Kaplan Giray'ı bölgeye göndermiştir. Ancak Kaplan Giray, Çerkezlerle karşılaşmadan Kalmukların baskınına uğramış ve yürüyüşünü durdurmak zorunda kalmıştır. ${ }^{10}$

II. Devlet Giray'dan sonra başa geçen I. Selim Giray ${ }^{11}$, oğlu Devlet Giray'ın Bucak taraflarındaki isyanı ile meşgul olduğundan Çerkez meselesi ile ilgilenememiştir. ${ }^{12}$ I. Selim Giray'ın yerine geçen III. Gazi Giray $^{13}$ ise otoriter bir yönetim sergileyememiştir. ${ }^{14}$ Çerkez meselesi 1707 'de Kırım hanı olan I. Kaplan Giray zamanında yeniden gündeme gelmiştir. $O$, başa geçince ilk iş olarak Çerkezlerin itaatlerini bildirmelerini istemiş ve Çerkezlerin ödedikleri yıllık vergi miktarını on kat arttırmıştır. Çerkezler, I. Kaplan Giray'a kendilerinden talep edilen vergiyi ödeyecek durumda olmadıklarını bildirmişlerdir. Bunun üzerine Kaplan Giray, içlerinde itaat etmiş olan Çerkezlerin de bulunduğu $20.000^{15}$ kişilik bir kuvvet ile Çerkezler üzerine yürümüştür. I. Kaplan

33, 2014, s. 153-155; Ali Barut, "Kırım Hanlığı ile Kuzey Batı Kafkasya İlişkilerinde Atalık Müessesesinin Yeri" Emel, S. 217, 1997, s. 21 vd.

${ }^{8}$ V. D. Smirnov, Osmanlı Dönemi Kırım Hanlığı, Çev. Ahsen Batur, İstanbul 2016, s. 468.

${ }^{9}$ II. Devlet Giray 1699-1702 ve 1708-1713 yılları arasında olmak üzere iki defa Kırım Hanlığının başına geçmiştir.

10 Seyyid Muhammed Rıza, Es-Sebü's-Seyyâr Fî Ahbâr-ı Mülûku't-Tatar, Haz. Mirza Kazım Bek, Kazan 1832, s. 269, 273.

${ }^{11} 1631$ 'de doğan I. Selim Giray, Kırım Hanlığını 1671-1677, 1684-1691, 1692-1699 ve 1702-1704 yılları arasında olmak üzere dört defa yönetmiştir.

12 Muhammet Şen, Kırım Hanlığı'nda I. Selim Giray Han Dönemi (1671-1704), Basılmamış Doktora Tezi, İzmir 2013, s. 182-183; H. Mustafa Eravcı, "Selim Giray", DiA, C.36, 2009, s. 428.

${ }^{13}$ III. Gazi Giray 1704-1707 yılları arasında hanlık makamında bulunmuştur.

${ }^{14}$ Henry H. Howorth, History of the Mongols from the 9th to the 19th century, Part II, Division 1, London 1880, s. 517.

${ }^{15}$ Henry H. Howorth bu rakamı 49.000 olarak vermektedir. (Howorth, a.g.e., s. 571).

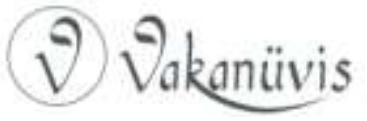


Giray, Kanjal Geçidi'ne geldiğinde, Çerkezler istenilen esirleri toplamak için ondan izin istemişlerdir. Bu süreçte beklemeye çekilen I. Kaplan Giray, geceleyin Çerkezlerin baskınına uğramış ve güçlükle canını kurtarabilmiştir. Bu yenilgi I. Kaplan Giray'ın Osmanlı Devleti tarafından görevinden alınarak Rodos'a sürgün edilmesine neden olmuştur. ${ }^{16}$

Kırım hanları 1709-1720 yılları arasında Osmanlı Devleti'nin Rusya ve Habsburglarla olan mücadelelerine katılmışlardır. Bu tarihler arasında hanların Kafkasya'da ciddi bir faaliyeti bulunmamaktadır. Osmanlı Devleti'nin dış politikada barışa dayalı bir siyaset takip etmeye başladığı 1720 yılında Kırım hanı III. Saadet Giray ${ }^{17}$, Çerkez meselesi ile yeniden meşgul olma fırsatını elde etmiştir. O, Salih Giray'ı ve Baht Giray'ı Çerkezler üzerine göndermiştir. Bunun üzerine Çerkezler -ki bunlar Kaytuk-biyoğulları, Canbulatoğlu ve Kabardeyler idi- Kaşka-Dağ civarında savunmaya çekilmişlerdir. Daha sonra bunlar istenilen miktarda esir vereceklerini vaat ederek Kırım kuvvetlerinin geri dönmesini sağlamışlardır. III. Saadet Giray, ordunun eli boş bir şekilde geri dönmesi üzerine bizzat ordunun başına geçip Çerkezler üzerine yürümüş, Çerkezleri eski yurtlarına geri döndürebilmek ve istenilen vergiyi ödemelerini sağlamak için kasabalarını tahrip etmiş, ürünlerine zarar vermiştir. Bunun üzerine Çerkezler Rusya'dan yardım istemişlerdir. Dönemin Rus çarı I. Petro, Astrahan'dan küçük bir Kazak kuvvetini onlara göndermiştir. Bu yardım Çerkezlere, III. Saadet Giray karşısında bir başarı sağlamamıştır, ancak Çerkezlerin Ruslarla yakınlaşmasına neden olmuştur. ${ }^{18}$

III. Saadet Giray, bolca ganimet ile Bahçesaray'a dönmüştür. Fakat ganimetin paylaştırılması sırasında ortaya çıkan bir anlaşmazlık, hanlığı yeni bir sorunla karşı karşıya getirmiştir. Kendisine ganimetten yetirince pay verilmediğini iddia eden Şirin beylerinden Can Timur, III. Saadet Giray'a karşı isyan bayrağını açmış ve Çerkez topraklarına kaçmıştır. Can Timur, burada Nogayları kendi tarafına çekmeye

\footnotetext{
${ }^{16}$ Silâhtar Fındıklılı Mehmed Ağa, Nusretnâme, C. II/II, s. 247; Joseph von Hammer, Kırım Hanlığı Tarihi, İstanbul 2013, s. 134-135; Seyyid Muhammed Rıza, a.g.e., s. 312; Howorth, a.g.e., s.571-572.

${ }^{17}$ III. Saadet Giray 1717-1724 yılları arasında Kırım Hanlığının başındadır.

${ }^{18}$ Smirnov, a.g.e., s. $468,469,470$.
} 
çalışmışsa da bunda başarılı olamamış ve uzun bir süre Çerkezler arasında yaşamıştır. ${ }^{19}$

Can Timur 1728'de hana karşı isyan eden Baht Giray'ın kendisine katılmasıyla güçlenmiştir. Baht Giray'ın bazı Nogayları kendi tarafına çekmesiyle isyan hareketi büyümüştür. Ancak Nogayların, Baht Giray'ın kendilerine karşı hazırladığı komplodan haberdar olup ondan desteklerini çekmeleriyle isyan sona ermiştir. Desteksiz kalan Baht Giray, affını rica etmiştir. Can Timur ise isyanında ısrar edip Şapsuğlar arasında yaşamaya devam etmiştir. Osmanlı Devleti'nin Şapsuğlar üzerinde baskı kurmasıyla ${ }^{20}$ Şapsuğlar Can Timur'a destek vermeyi bırakmış, Can Timur da Kalmuklara sığınmak zorunda kalmıştır. ${ }^{21}$ Şapsuğların isyancı Çerkezler arasında yer almadı̆̆ını belirtmek gerekir. Her ne kadar onlar isyancılara kucak açmışlarsa da bu durum Çerkezlerin konukseverliklerinden ileri gelmektedir. ${ }^{22}$

Dönemin Kırım hanı II. Mengli Giray ${ }^{23}$, başlarında kardeşleri Baht Giray ve Murad Giray'ın bulunduğu bir kuvveti 1729 'da isyan halindeki Çerkezlerin üzerine göndermiştir. Bunun üzerine Çerkezler hana vergi ödeyeceklerine dair söz vermişler ve hediye olarak da büyük bir köle grubunu Baht Giray ve Murad Giray'ın konakladığı ordugaha göndermişlerdir. Kırım kuvvetleri bunu bir zafer olarak kabul etmişler ve eğlenceye başlamışlar, ancak bu sırada Çerkezlerin baskınına uğramışlardır. Bu baskında II. Mengli Giray'ın iki kardeşi de hayatını kaybetmiş, ordu ise bozguna uğramıştır. ${ }^{24}$

Nihayet Kırım Hanlığı, Osmanlı Devletinin yardımı ile Çerkezleri itaat altına almayı başarmıştır. Aslında bu, doğrudan Çerkezler üzerine

\footnotetext{
${ }^{19}$ Smirnov, a.g.e., s. 474-479; Râşid Mehmed Efendi-Çelebizâde İsmâil Efendi, Târîh-i Râşid ve Zeyli, Haz. Abdülkadir Özcan vd., C. III s. 1602-1603; Hammer, a.g.e., s. 137, 140, 141; İsmail Hakkı Uzunçarşılı, Osmanlı Tarihi, C. IV, II. Kısım, Ankara 1995, s. 10; Howorth, a.g.e., s. 575-576; Seyyid Muhammed Rıza, a.g.e., s. 330.

${ }^{20}$ Bu noktada Osmanlı Devleti, Şapsug Beyi ile dostluğu bulunan Soğucak Kalesi Bina Emini Mehmed'den yararlanmaya çalışmıştır. (BOA. MD. 133, h. 1264).

${ }^{21}$ Smirnov, a.g.e., s. 474-479.

${ }^{22}$ Evliya Çelebi, Evliya Çelebi Seyahatnâmesi, C. VII, Haz. Yücel Dağlı-Seyit Ali Kahraman-Robert Kahraman, İstanbul 2003, s. 280.

${ }^{23}$ II. Mengli Giray $1724-1730$ ve $1737-1739$ yılları arasında olmak üzere iki defa Kırım Hanı olmuştur.

${ }^{24}$ Julius von Klaproth, Travels in the Caucasus and Georgia, London 1814, s. 191-192.
}

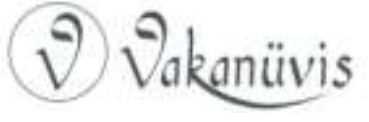


düzenlenmiş bir sefer sonucunda gerçekleşmemiştir. Osmanlı Devleti 1732 yılında İran ile yapılan savaşa katılması için Kırım hanı I. Kaplan Giray'ın, kuvvetleriyle birlikte Kafkaslar üzerinden Azerbaycan'a gelmesini istemiştir. Kaplan Giray'ın bu yürüyüşü, aslında Kafkaslarda ve Dağıstan'da Osmanlı egemenliğini pekiştirmek gibi bir amaca hizmet etmektedir. Nitekim $\mathrm{O}$, yol boyunca Kafkasya ve Dağıstan idarecilerinin itaatlerini kabul etmiştir. ${ }^{25}$

I. Kaplan Giray, 1732 yılındaki askeri yürüyüşü ile Çerkezleri itaat altına almayı başarmıştır. Ancak bu durum uzun sürmemiştir. Osmanlı Devleti'nin 1739 'da Rusya ile imzaladığı anlaşma ile Kabardeyler bağımsızlıklarını elde etmişlerdir. ${ }^{26}$ Bundan sonraki süreçte Çerkezlerin, hanlığa olan bağlılıklarını sürdürmekle beraber onlara düzenli bir şekilde vergi ödemedikleri görülmektedir. 1748'de Kırım Hanı olan Arslan Giray, belki de bu yüzden art arda Çerkezler üzerine seferler düzenlemiştir. Ancak bu seferler Kırım için bir yarar sağlamamıştır. ${ }^{27}$

\section{Kırım Hanlığının İdaresinde Nogaylar}

Kuban Boyunda yaşayan Nogaylar, Kuban Seraskeri tarafından idare edilmişlerdir. Kuban Seraskerliği 1577 'den sonra ortaya çıkmış bir kurumdur. Bu tarihte ìtil ve Yayık boylarında görülen kuraklık neticesinde buralarda yaşayan Nogaylardan bir grup Kırım taraflarına göç etmiş, dönemin Kırım hanı I. Devlet Giray bunları Azak ve Kuban taraflarına yerleştirmiş ve başlarına da oğullarından birisini idareci olarak atamıştır. ${ }^{28}$

Giray hanedanından sultanlar arasından seçilen Seraskerler, Nogaylar ile hanlık arasındaki bağlantıyı sağlamakta, bu açıdan Nogayların hanın sarayındaki temsilcisi konumunda bulunmaktadırlar. Nogay beyleri bu seraskerlere bağlıdır ve savaş zamanında Nogay

\footnotetext{
${ }^{25}$ Hammer, a.g.e., s. 143; Subhî Mehmed Efendi, Subhî Tarihi, Haz. Mesut Aydıner, İstanbul 2007, s. 288-289.

${ }^{26}$ Subhî Mehmed Efendi, a.g.e., s. 594.

27 Saîd Giray, Târîh-i Saîd Giray Hân, staatsbibliothek zu Berlin, Osmanische Sammelhandschrift, Hs. Or. 923, vr. 144a.

${ }^{28}$ Akdes Nimet Kurat, IV-XVIII. Yüzyıllarda Karadeniz Kuzeyindeki Türk Kavimleri ve Devletleri, Ankara 1992, s. 282.
}

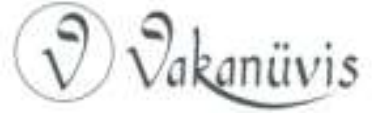


kuvvetleri seraskerlerin komutasındadırlar. Nogaylar arasındaki hukuki işlere bakan görevliler de seraskerlere bağlıdırlar. ${ }^{29}$ Seraskerlik kurumu idari, askeri ve adli yetkileriyle Nogayları Kırım Hanlığı ile bütünleştirmektedir. Ancak bu durum Kırım hanlarının Nogayları itaat altında tutmalarını kolaylaştırmamıştır. Nogaylar özellikle iktisadi buhranlarla karşılaştıklarında ülkeyi terk etmekten ya da hanlığa isyan etmekten geri durmamışlardır. Orak Mirza'nın Rus Çarlığına ilticası, Gazi Giray (1704-1707) döneminde Anapa etrafında oturan Nogayların isyanı ve 1727 'de bazı Nogay gruplarının Baht Giray Sultan'ın isyanına katılmaları bunlara emsal teşkil etmektedir. ${ }^{30}$

Kırım hanları isyan eden Nogaylara karşı askeri müdahalede bulunmaktan kaçınmışlar, isyan eden topluluklara nasihat heyetleri göndererek isyanları sona erdirmeyi denemişlerdir. En azından XVIII. yüzyılın ilk yarısında Nogay isyanları karşısında hanların tutumu bu şekildedir. ${ }^{31}$ Kırım hanları isyan sona erdiğinde karışıklığa sebep olan grupları bir başka bölgeye göçürebilmektedirler. ${ }^{32}$

Kırım Hanlığı Nogaylara yönelik ılımlı bir siyaset takip etmiştir. Bu durum aynı kökenden gelmelerinden ziyade, Nogayların sahip oldukları askeri güçten ve hanlık ekonomisine sağlayabilecekleri katkıdan kaynaklanmıştır. Nogaylar gerekli hallerde hanlık ordusuna askeri destek verebilmekte ve Şirin beyleri ile ortaklaşa yönetim sergileyen Giray hanedanını Şirin beylerine karşı güçlendirebilmektedirler. ${ }^{33}$ Ayrıca yerleşik hayata geçmeleri durumunda boş arazilerin ya da harap

\footnotetext{
${ }^{29}$ W. Eton, A Survey of the Turkish Empire in which are Considered, London 1799, s. 326.

${ }^{30} \mathrm{Bu}$ konuya etnik yapı başlığı altında temas edildiğinden yeniden anlatımına gerek duyulmamıştır.

31 Smirnov, a.g.e., s. 479. Halim Giray zamanında Bucak-Yedisan bölgesindeki Nogayların isyanını bastırmak için Nogaylara nasihat heyetleri gönderilmiştir. (İsmail Bülbül "Yedisan-Bucak Nogaylarının 1756 ve 1758 İsyanları", Türk Tarihi Araştırmaları Dergisi, Yıl 1, Sayı 1, 2016, s. 104.)

${ }^{32}$ Kırım Hanlarına Nâme-i Hümâyûn (2 Numaralı Name Defteri), Haz. Murat Cebecioğlu vd., İstanbul 2013, s. 177.

${ }^{33}$ Saîd Giray, a.g.e., vr. 105b; Smirnov, a.g.e., s. 210; Maria İvanics, "Bozkırdaki Bir Kabilenin Kökeni ve Yükselişi: Şirinler", Çev. Mustafa Işık, Doğu Avrupa Türk Mirasının Son Kalesi Kırım, İstanbul 2015, s. 55 vd.; Alper Başer, "Kırım Hanlığı Tarihinde Mangıt Kabilesi", Doğu Avrupa Türk Mirasının Son Kalesi Kırım, İstanbul 2015, s. 78 vd.; Paşaoğlu, a.g.m., s. 166 vd.
}

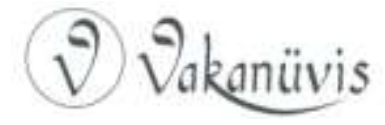


köylerin şenlenmesini ve zirai üretimin artmasını sağlayabilmektedirler. ${ }^{34} \mathrm{Bu}$ yüzden Kırım hanları, Nogayları yerleşik hayata geçmeye teşvik etmektedirler.

\section{Osmanlı Devleti'nin Kuzey Kafkasya Politikası}

Hacı Giray'ın 1466'da ölümünden sonra oğulları arasında başlayan taht kavgası Osmanlı Devleti'nin Kırım Hanlığına müdahale etmesine imkan vermiş, 1475'te Gedik Ahmed Paşa komutasında gönderilen bir donanma ile hanlığın Osmanlı Devleti'nin tabiiyetine girmesinin yolu açılmış ve yüzyıl sona ererken hanlık, Osmanlı Devleti'nin bir parçası haline gelmiştir. ${ }^{35}$ Osmanlı Devleti, hanlığın mevcut siyasi ve idari yapısına müdahale etmemiş, hanların idaresinde olan bölgelerin yönetimini yine hanlara bırakmıştır. Öte yandan bölgede Cenevizlilerden alınan Kefe, Azak, Taman gibi yerler doğrudan Osmanlı Devleti'ne bağlanmıştır. ${ }^{36}$

Şu haliyle Nogayların ve Çerkezlerin idaresinden Kırım hanları sorumlu gibi görünmektedir. Bununla birlikte gerekli görüldüğünde Nogay ve Çerkez beylerine İstanbul'dan emirler gönderilebilmektedir. Ayrıca Azak, Taman, Temrük ve Anapa'da bulunan kadı, mütesellim, bina emini gibi devlet görevlilerinin bölgedeki beylerle sürekli iletişim halinde olması sultanın otoritesinin Nogaylar ve Çerkezler arasında yayılmasına imkan vermiştir. Buna ilaveten adı geçen yerlere bazen Çerkez soylularından kişiler atanmış, böylelikle Çerkezlerin Osmanlı Devleti'ne olan bağlılıkları arttırılmıştır.

XVI. yüzyılın ikinci yarısında Rus Çarlığının Astrahan'ı ele geçirmesi Osmanlı Devleti'nin Kuzey Kafkasya'daki egemenliğine gölge düşürmüştür. Bunun üzerine Osmanlı Devleti 1568'de Astrahan'a bir sefer düzenlemiştir. Sefer başarısızlıkla sonuçlanmış, Rusların Astrahan ve Terek Boyunun aşağı kısımlarındaki egemenlikleri kalıcı hale gelmiştir. Osmanlı Devleti, Astrahan Seferi ile kaybettiği itibarını Özdemiroğlu Osman Paşa'nın Kafkasya'daki askeri ve siyasi

\footnotetext{
${ }^{34}$ Saîd Giray, a.g.e., vr. 105b.

${ }^{35}$ Halil İnalcık, "Kırım Hanlığı”, iA, C. 6, ìstanbul 1977, s. 747.

${ }^{36}$ Yücel Öztürk, "Doğu Avrupa Türk Mirasının Son Kalesi: Kırım Hanlığı”, Doğu Avrupa Türk Mirasının Son Kalesi Kırım, Ed. Yücel Öztürk, İstanbul 2015, s. 17; Evliya Çelebi, a.g.e., s. 248, 266, 337, 338.
}

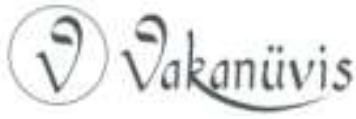


faaliyetleriyle yeniden kazanmıştır. ${ }^{37}$ Bundan sonraki süreçte Ruslar, doğrudan bölgeye müdahale etmek yerine Kazakları ve Kalmukları kullanarak bölgeyi siyasi ve iktisadi açıdan istikrarsız bir hale getirmeye çalışmışlardır. Kazak ve Kalmuk saldırılarına karşı Kırım Hanlığı ve Osmanlı Devleti bölge ahalisini korumak için bazı yerlerde kaleler inşa etmiştir.

Ruslar 1696'da Azak Kalesi'ni ele geçirince Osmanlı Devleti'nin Kafkaslardaki etkinliği artmıştır. Bu noktada Osmanlı Devleti hem Rusların hem de Kazakların Karadeniz'e çıkışlarını engelleyebilmek için Azak Denizi kıyısındaki stratejik bölgelerde kaleler inşa etmiş ve Rusların bölge ile olan temasını en az indirgemek amacıyla Azak Kalesi'ne giden ticaret yollarına sıkı bir denetim getirmiştir. Buna ilaveten, Kazak ve Kalmuk saldırılarına karşı bölge ahalisini askeri açıdan desteklerken saldırıların önlenmesi için Rusya üzerinde diplomatik baskı kurmuştur. Yine, 1730 yılında İran'a savaş ilan edildiğinde, Kafkaslardaki Osmanlı hakimiyetini güçlendirmek için Kırım kuvvetlerinin Kafkaslardan geçerek orduya katılması istenmiştir. ${ }^{38}$ Kafkaslardaki Osmanlı egemenliğini korumaya yönelik atılan bu adımların uzun vadeli getirileri olmamış, Osmanlı Devleti 1739'da Kabardeyler, 1774 'te ise Kırım Hanlığı üzerindeki haklarını kaybetmiştir.

\section{Rusların Kuzey Kafkasya'da Nüfuz Kazanma Çabaları}

IV. İvan ${ }^{39}$, 1552'de Kazan ve 1556'da Astrahan Hanlıklarını hakimiyetini altına almış, böylelikle Rusya'nın sınırlarını Kuzey Kafkasya'ya kadar genişletmiştir. Bundan sonra IV. İvan, bölgedeki Nogay ve Çerkez gruplarını kendi tarafına çekmeye ve bunları Kırım Hanlığına karşı kışkırtmaya çalışmıştır. ${ }^{40}$ Bunu yaparken de mümkün olduğunca Osmanlı Devleti'nin tepkisini çekmemeye çalışmıştır. ${ }^{41}$

\footnotetext{
${ }^{37}$ Kırım Hanlarına Nâme-i Hümâyûn (2 Numaralı Name Defteri), s. 8-14; Evliya Çelebi, a.g.e., s. 255, 278, 279.

${ }^{38}$ Şem'dânî-zâde Fındıklııı Süleyman Efendi, Mür'i't Tevârih, C. I, Haz. Münir Aktepe, İstanbul 1976, s. 41.

${ }^{39}$ IV. İvan 1547-1584 yılları arasında Rus hüküm sürmüş Rus çarıdır.

40 Muzaffer Ürekli "Rus Yayılması Karşısında Kırım Hanlığı ve Kafkasya", Kafkasya Araştırmaları I, İstanbul 1988, s. 13, 14.

${ }^{41}$ Mustafa Budak, "Rusya'nın Kafkasya'da Yayılma Siyaseti”, Türkler, C. 18, Ankara 2002, s. 489.
} 
Bununla birlikte Rus sınırına yakın olan bölgelerde yaşayan Çerkezlerle doğrudan temas kurmaktan da çekinmemiştir. 1557'de Kırım Hanlığı ve Tarku Şamhallığı ${ }^{42}$ karşısında yardım isteyen Temryko'nun çağrısına cevap vermiş, ayrıca 1567'de Temryko'nun kızıyla evlenerek onu Rusya'ya tabi kılmaya çalışmıştır. ${ }^{43}$ Ertesi yıl Osmanlı Devleti, Astrahan üzerine bir sefer düzenlemiştir. Sefer sonunda IV. İvan, Osmanlı Devleti'nin Çerkezler üzerindeki hakimiyetini tanımak zorunda kalmıştır. $^{44}$

XVII. yüzyıla gelindiğinde Rusların Kafkaslarda daha etkili olduğu görülmektedir. Ancak bunun doğrudan Rus diplomatlarının ya da askerlerinin girişimleri sonucunda gerçekleşmediğini belirtmek gerekir. Ruslar, XVII. yüzyılda İtil Boyu'nda görülen Kalmukları ve Karadeniz'in kuzeyindeki Kazakları himaye ederek bunları Kırım topraklarına akın düzenlemeleri konusunda teşvik edip desteklemişlerdir. ${ }^{45}$

XVIII. yüzyılın ilk çeyreğinde Osmanlı Devleti ile Rusya arasında imzalanan iki anlaşma, Kırım topraklarının yoğun bir şekilde Kazak ve Kalmuk akınlarına maruz kaldığını ortaya koymaktadır. ${ }^{46}$ Osmanlı Devleti tarafından 1721'de elçi olarak Rusya'ya gönderilen Mustafa Ağa, Kazakların ve Kalmukların bu akınlarından duyulan rahatsızlığı dile getirmiştir. ${ }^{47} 1722$ 'de orta elçi statüsüyle Moskova'ya gönderilen Nişli Mehmed Ağa'nın gündeminde yer alan konulardan birisi de yine Kazakların ve Kalmukların Çerkezler ve Nogaylar üzerine düzenledikleri akınlardır. ${ }^{48}$ XVIII. yüzyıl Osmanlı tarihçilerinden Şemdanîzâde Süleyman Efendi, Mür'i't-tevârih'inde 1736'da Osmanlı Devleti'nin

\footnotetext{
${ }^{42}$ Tarku Şamhallığı, XVI. yüzyılda, Kumuklar tarafından Dağıstan'daki kurulmuş bir Türk Devletidir. Bkz. İsmail Bülbül, Başlangıcından Rus Hakimiyetine Kadar Kumuk Türkleri ve Tarku Şamhallı̆̆ı, Basılmamış Tezi, Sakarya 2011.

${ }^{43}$ Baturay Özbek, Çerkez Tarihi Kronolojisi, Ankara 1991, s. 31.

${ }^{44}$ inalcık, a.g.m., s. 748.

45 Oktay Berber, "Kafkasya'da Moğol Kökenli Bir Halk: Kalmuklar”, Yeni Türkiye (Kafkaslar Özel Sayısı), S. 71, C. II, s. 368; Mehmet Alpargu, Nogaylar, İstanbul 2007, s.111.

${ }^{46}$ Râşid Mehmed Efendi-Çelebizâde İsmâil Âsım Efendi, Târîh-i Râşid ve Zeyli, Haz. Abdülkadir Özcan vd., C. I, s. 591; Ahmed Cavid Bey, Osmanlı Rus iliş̧kileri Tarihi, Haz. Adnan Baycar, İstanbul 2004, s. 182.

${ }^{47}$ BOA. MD. 131, h. 1228

${ }^{48}$ Aydın Mertayak, Nişli Mehmed Ağa'nın Rusya Sefareti ve Sefaretnamesi (17221723), Basılmamış Yüksek Lisans Tezi, Tokat 2005, s. 62.
}

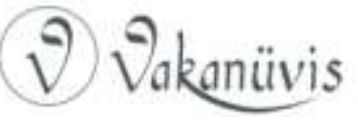


Rusya'ya savaş ilan etme nedenlerinden birisi olarak Rusların Kafkaslardaki faaliyetlerini göstermektedir. ${ }^{49}$ Kısacası bölgeye yönelik Kazak ve Kalmuk akınları süreklilik arz etmektedir ve bu akınlara süreklilik kazandıran ise Rusların Kafkaslara egemen olma düşüncesidir.

Rus Çarlığı 1736'da Osmanlı Devleti'ne savaş ilan ettiğinde Osmanlı Devleti ile Rusya arasındaki savaş Kırım Yarımadası ve yarımadanın batısında kalan topraklarda gerçekleşmiştir. Ancak Ruslar bu esnada Kafkas hakimiyeti için Kalmukların lideri olan Dondok Ombo önderliğinde 27.000 kişilik bir kuvveti -ki bunların 20.000'i Kalmuklardan oluşmaktadır- Kuban Boyuna göndermiş, bu kuvvetler bölgedeki Nogayları ve Çerkezleri kılıçtan geçirmiştir. ${ }^{50}$ Savaşı sonlandıran Belgrad Anlaşması ile Osmanlı Devleti Kabardeyler üzerindeki haklarından vazgeçmiş, buna karşılık Ruslar Osmanlı Devleti'nin Kuban Boyundaki hakimiyetini tanımıştır. ${ }^{51}$ Ruslar bu anlaşmaya çok fazla sadakat göstermemişlerdir. Nitekim Osmanlı Devleti, 1741'de Rusların kendilerini Gürcülerin, Kabardeylerin ve Dağıstan'ın hakimi olarak ilan etmelerine karşı çıkmış ve bu durumun düzeltilmesi için Rus makamlarına ısrarlı bir şekilde itirazlarını iletmiştir. ${ }^{52}$ Nihayet Ruslar geri adım atmak zorunda kalmışlardır. Fakat Kafkaslara yönelik emellerinden vazgeçmemişlerdir.

\section{Etnik Gruplar Arasındaki İlişkiler}

Kuban Boyunda yaşayan Nogaylar ile Çerkezler arasında dostane ilişkiler bulunmaktadır. Bu dostluğun iki topluluğun sahip olduğu ortak değerlerden doğduğu söylenebilir. Buna göre her iki topluluk da benzer bir yaşayış tarzı sergilemekte, aynı coğrafyayı paylaşmakta, Kalmukları ya da bölge dışında yaşayan Kazakları ortak düşman olarak görmekte ve Kırım hanlarına ve Osmanlı sultanlarına itaat etmektedirler. İki topluluk için de Altın Orda çağından itibaren kısmen ortak bir tarih bulunmaktadır. İslamiyet Nogaylar tarafından tamamen, Çerkezler tarafından ise kısmen kabul edilmiş bir dindir. Eski inançlarını sürdüren Çerkezler ise İslamiyet'e büyük bir saygı duymaktadırlar. Her iki

\footnotetext{
${ }^{49}$ Şem'dânî-zâde Fındıklılı Süleyman Efendi, a.g.e., s. 41.

${ }^{50}$ Berber, a.g.m., s. 370-371.

${ }^{51}$ Ahmed Cavid Bey, a.g.e., s. 240, 241.

${ }^{52}$ Ahmed Cavid Bey, a.g.e., s. 259.
}

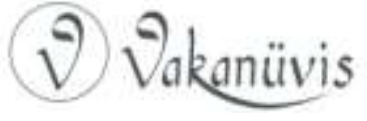


topluluğun da sanat anlayışlarında, geleneklerinde, bazen de dünya görüşlerinde benzerlikler bulunmaktadır. Bütün bu ortak özellikler iki toplumu birbirine yakınlaştırmıştır. Bu durum onların genelde birlikte hareket etmelerine imkan vermiştir.

Kazakların Nogaylarla Rusya üzerine ortaklaşa akın tertip ettikleri bilinmektedir. Burada ortak düşman iki toplumu birbirine yakınlaştırmış gibi görünmektedir. Ancak gündelik hayatta KazakNogay ya da Kazak-Çerkez ilişkilerinde başka etkenler de rol oynamaktadır. Başbakanlık Osmanlı Arşivinde bulunan 134 Numaralı Mühimme Defterinde yer alan bir kayıt bu grupların birbirleri ile olan ilişkilerine ışık tutmaktadır. Bu kayıtta 1727 yılında meydana gelen iki farklı olay anlatılmaktadır. Birinci olay Abhazların Soğucak yakınlarındaki Edincik köyüne yaptıkları baskınla alakalıdır. Buna göre yaklaşık 300 Abhaz, Ağustos ayında, gün doğumundan önce Edincik'e saldırmış, köyü yağmalayıp 30 kadar Müslümanı da esir almıştır. Daha sonra esirleri ve köyden aldıkları tuzu ${ }^{53}$ kayıklara yükleyip ülkelerine hareket etmişlerdir. Baskını duyan Taman Mütesellimi 22 Kazakla birlikte tonbazlara ${ }^{54}$ binip kayıklara yetişmiştir. Kazaklar, Abhazların 8 kayığından birisini batırmış, birkaç kişiyi de esir almışlardır. Diğerleri Kazaklardan kurtulmuştur. Karadan giden Abhazlar ise Taman süvarileri ile meydana gelen küçük bir çatışmanın ardından kaçmayı başarmışlar ve önce muhtemelen deniz yoluyla gelen Abhazlarla birleşmek için Şekayege sınırındaki Gök denilen mahallin limanına gitmişler, daha sonra ise bu limanın ardındaki dağlarda savunmaya çekilmişlerdir. Olay Soğucak'ta duyulduğunda Abhazlarla dostluğu bulunan Soğucak bina emininin hazinedarı bölgeye gelmiş ve esirlerin serbest bırakılmasını sağlamıştır. ${ }^{55}$

İkinci olay yine Soğucak ile bağlantılıdır. Soğucak Kalesi'nden sorumlu olan Abdullah Paşa, bir adamını yağ satın alması için Nogaylara göndermiştir. Görevli kişi, Nogaylardan aldığı 14 tulum yağı

${ }^{53}$ Abhazlar tuz ihtiyacını Kırım'dan sağlamaktadırlar. Ancak Kırım hanı, o dönemde itaatsizlik gösteren Abhazları yeniden itaat altına alabilmek için İstanbul nezdinde girişimde bulunarak Abhazlara başta tuz olmak üzere her türlü gıda maddesinin ve eşyanın satışının yasaklanmasını sağlamıştır. Abhazlar da muhtemelen tuz ihtiyacını gidermek için Edincik'e saldırmışlardır. (BOA. MD. 133, h. 1263; BOA. MD. 153, h. 220)

${ }^{54}$ Tonbaz, altı düz biçimde olan kayığa verilen isimdir.

${ }^{55}$ BOA. MD. 134, h. 726.

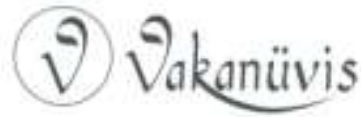


Ağnad Kazaklarının tonbazlarına yükleyip Kuban üzerinden Kızıltaş Boğazı'na gelmiştir. Burada, Taman Mütesellimi ve Kızıltaş Dizdarı, Karadeniz'de ticaret gemilerinin gidiş-gelişlerine getirilen kısıtlamayı gerekçe göstererek tonbazlara el koymuşlardır. Bu esnada Soğucak Kalesi'nin imarı için havale edilen parayı Soğucak'a götüren Soğucak bina emininin hazinedarı yaşanan tartışmaya rast gelmiştir. Olaya müdahale eden hazinedar el konulan yağ tulumlarının 7'sini zorla alarak Soğucak'a gitmiştir. Hazinedar, olayları Soğucak'ta bulunan Şegayeke Beyi Kanpolad'a anlatmıştır. Kanpolad ise bir miktar adamını hem denizden hem de karadan Kızıltaş'a göndermiştir. Bunlar alıkonulan tonbazları ele geçirip zorla Kızıltaş Kalesine girmişler ve kale dizdarını darp etmişlerdir. Kalenin gümrükçüsünü tutuklayıp ardından Soğucak'a geri dönmüşlerdir. ${ }^{56}$

Birinci olayda adı geçen Edincik bir Tatar ya da Çerkez yerleşkesidir. Saldırıyı gerçekleştirenlerle mücadelede Kazaklar önemli bir rol oynamıştır. Saldırıda esir alınanları kurtaran hazinedar Soğucak'taki bir devlet görevlisidir. Hazinedarın Abhazlarla olan dostluğu onun Kafkas kökenli birisi olabileceğini akla getirmektedir. İkinci olayda ise Nogaylar önemli bir yağ üreticisi olarak görülmektedir. Kazaklar onların ürettikleri yağları bir başka bölgeye götüren nakliyecilerdir. Yağların taşınması sırasında karşılaşılan güçlükleri ise Çerkezler ortadan kaldırmıştır. Öte Abdullah Paşa ile Taman Mütesellimi arasındaki uyuşmazlık, bölge sakinlerini merkezi otorite ile karşı karşıya getirmiştir.

\section{Etnik Yapı}

XVIII. yüzyılın ilk yarısında Kuban Boyunda egemen olan etnik unsurlar Türkler ve Çerkezlerdir. Bunların dışında Rus yönetimi ile anlaşmazlığa düşen bazı Kazak gruplarının XVII. yüzyılın sonlarına doğru bölgeye göç etmeye başladıklarını belirtmek gerekir. Bunlar, XVIII. yüzyıldaki Kazak göçleriyle birlikte bölgenin üçüncü önemli etnik grubu haline gelmişlerdir.

Çerkezler bölgenin otokton halklarındandır. Bunlar, Ukrayna düzlüklerini de içine alan geniş bir sahada yaşarken çeşitli kavimlerin baskısı sonucunda Kuban Nehri'nin güneyine doğru itilmeye

${ }^{56}$ BOA. MD. 134, h. 726.

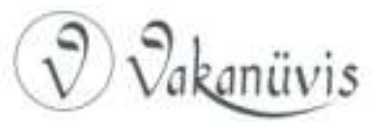


başlamışlardır. ${ }^{57}$ XVIII. yüzyılın ilk yarısında Çerkezlerin yoğun olarak yaşadıkları bölge Kuban Nehri'nin güneyi ile Kafkas Dağları arasında kalan sahadır. Bununla birlikte nehrin kuzeyinde, bilhassa Taman Yarımadası'nda, dikkate değer bir Çerkez nüfusundan söz etmek mümkündür. Yarımadada yaşayan Çerkezler Jane ya da Cane Çerkezleri adıyla anılmaktadır. Jane Çerkezlerinin merkezi, Kuban Nehri kıyısında bulunan Jane kasabasıdır. Jane Çerkezlerinin beyi bu kasabada oturur ve bu bey Taman Yarımadası'nda kendisine bağlı 300 kadar Çerkez yerleşiminin idaresinden sorumludur. ${ }^{58}$ Ayrıca bölgenin güvenliğini sağlamak $^{59}$ ve Azak Kalesi'nin intiyaç duyduğu tahılı tedarik etmek gibi iki önemli vazifeye de sahiptir. ${ }^{60}$ Bütün bu görevler Jane beyini hanlık bünyesindeki itibarlı beyler arasına taşımış, ${ }^{61}$ belki de Jane Çerkezleri arasında İslamiyet'in geniş ölçüde kabul görmesinin yolunu açmıştır. ${ }^{62}$

Taman Yarımadası'nda Jane'den sonra ikinci önemli Çerkez yerleşimi Temrük'tür. Temrük, Kuban Nehri ile Taman kasabası arasında I. Selim ${ }^{63}$ zamanında inşa edilmiş ahşaptan bir kaledir. XVII. yüzyılın ortalarında kale içinde yaklaşık 100, kale varoşunda ise 700 hane bulunmaktadır. Kalede oturan askerin dışında hanelerin sakinleri Müslüman Çerkezlerdir. Temrük'ü Jane'den ayıran en önemli farklııı ise burasının aynı zamanda bir üretim ve ticaret merkezi olmasıdır. ${ }^{64}$ Ancak Kuban Boyundaki hiçbir yerleşim yeri Taman'ın sahip olduğu özelliklerle boy ölçüşemez.

Taman kasabası bir sancak merkezidir. Dolayısıyla sancakta bulunması gereken askeri, idari ve mali yapıları burada görmek mümkündür. Bunun dışında medrese, okul ve camileriyle bir eğitim ve kültür merkezidir. Sahip olduğu özellikler bunlarla sınırlı değildir.

\footnotetext{
${ }^{57}$ Mirza Bala, "Çerkesler", iA, C. 3, İstanbul 1995, s. 375.

${ }^{58}$ Kornrumpf, a.g.m., s. 250.

59 Derya Derin, Abdülgaffar Kırımînin Umdet'ül-Ahbar'ına (Umdet'üt-Tevarih) Göre Kırım Tarihi, Basılmamış Yüksek Lisans Tezi, Ankara 2003, s. 336.

${ }^{60}$ Yücel Öztürk, "Osmanlı Karadenizi Hakkında Bir Risale", Karadeniz Araştırmaları, S. 13 (Bahar 2007), s. 86.

${ }^{61}$ Kornrumpf, a.g.m., s. 250.

${ }^{62}$ Hezarfen Hüseyin Efendi, a.g.e., s. 172.

${ }^{63} 1743-1748$ yılları arasında hüküm sürmüştür.

${ }^{64}$ Evliya Çelebi, a.g.e., s. 268; Kornrumpf, a.g.m., s. 250; Âşık Mehmed, Menâzırü'lAvâlim, C. III, Haz. Mahmut Ak, Ankara 2007, s. 1101.
} 
Taman, 200 kadar dükkanıyla Kuban Boyu için bir ticaret üssüdür. Bundan dolayı Türkler ve Çerkezler dışında Rum, Ermeni ve Yahudi tüccarların da oturduğu kozmopolit bir kasaba görüntüsü arz eder. ${ }^{65}$

Bölgedeki diğer önemli Çerkez yerleşimleri Soğucak, Anapa ve Kızıltaş'tır. Soğucak 400, Anapa 100, Kızıltaş ise 80 haneli aynı isimlerdeki kale ve bu kalelerin varoşlarından oluşan yerleşim yerleridir. ${ }^{66} \mathrm{Bu}$ yerleşim yerlerinde meskun olanlar muhtemelen Çerkezlerin Şegayek kolundandır. ${ }^{67}$ Onların doğusunda Terek Boyuna kadar uzanan sahada sırasıyla Natukhaylar, Hatukaylar, Bzeduglar, Temirgoylar, Besleneyler, Kabardeyler oturur ki her biri Çerkezlerin önemli bir boyu sayılmaktadır. Çerkezlerin güneybatısında ise Abhazlar ${ }^{68}$ yaşamaktadır. ${ }^{69}$

Kuban Nehri'nin güneyinde sıralanmış bu Çerkez boylarına ait yerleşim yerleri hakkında bilinenler çok azdır. XVII. yüzyılın ünlü seyyahlarından Evliya Çelebi'nin açıklamaları bunun nedenine dair ipuçları vermektedir. Buna göre Çerkezler başta savunma kaygısı olmak üzere inançlarından, geleneklerinden, iktisadi zihniyetlerinden ve sağlıkla ilgili meselelerden kaynaklanan bir takım sebepler yüzünden bir bölgede uzun süre oturmamaktadırlar. ${ }^{70} \mathrm{Bu}$ haliyle onlar kısmen göçebe bir hayat sürmektedirler ve kendilerine ait sınırlar içerisinde düzensiz aralıklarla göç etmektedirler. Bu yüzden Çerkezlerde şehircilik pek fazla gelişmemiştir. Bu durum tarihçilerin ya da seyyahların Çerkezlere ait yerleşim yerlerine nadiren değinmelerine yol açmış olabilir.

Kuban Boyunun ikinci önemli etnik grubu Türklerdir. Türkleri Osmanlı Türkleri, Kırım Türkleri/Tatarlar ve Nogaylar olmak üzere üç

65 Evliya Çelebi, a.g.e., s. 266-267; Âşık Mehmed, a.g.e., s. 1019-1020; A. De La Motraye, a.g.e., s. 40; Kornrumpf, a.g.m., s. 249.

${ }^{66}$ Evliya Çelebi, a.g.e., s. 269, 277

${ }^{67}$ BOA. MD. 133, h. 1264.

68 Abhazlar, Kuzey Kafkasya halklarındandır. Kökenleri konusu henüz aydınlatılamamıştır. Bazı Rus, Gürcü ve Abhaz tarihçiler, onların Mısır'dan geldiklerini ileri sürmüşlerdir. (Alexandre Grigoriantz, Kafkasya Halkları, İstanbul 1999, s. 138-139; Ufuk Tavkul, Kafkasya Gerçeği, İstanbul 2007, s. 125-126)

${ }^{69}$ Adolf Berje, Kafkasyalı Dağı Kavimlerin Kısa Tasvirleri, Çev. Murat Papşu, Ankara 1999, s. 12 vd.

${ }^{70}$ Evliya Çelebi, a.g.e., s. 280.

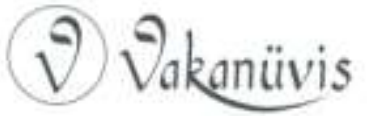


alt başlık altında incelemek mümkündür. Osmanlı Türkleri, Kuban Nehri'nin Karadeniz ve Azak Denizi'ne döküldüğü sahil şeridindeki kentlerde ve kalelerde oturmaktadırlar. Tatarların da benzer bir iskan kuşağı bulunmaktadır. Ancak onların bazen Çerkez topraklarında da oturdukları görülür. ${ }^{71}$ Bununla birlikte bu iki alt grup Nogaylarla kıyaslandığında Kuban Boyundaki Türk nüfusu içerisinde önemli bir yer teşkil etmez.

Nogaylar, ağırlıklı olarak Kuban Nehri'nin kuzeyindeki bozkırda yaşamaktadır. Ancak nehrin güneyinde, Çerkez topraklarında yaşayan Nogay nüfusu da göz ardı edilemeyecek kadar çoktur. Nogaylar, Kuban Boyu'na XVI. yüzyılın ortalarında gelmeye başlamıştır. ${ }^{72}$ Bu göç dalgası, XVII. yüzyılın başlarında Kalmukların İtil civarında görülmeleriyle süreklilik kazanmıştır. ${ }^{73}$

Kalmukların dikkat çeken ilk faaliyeti 1628 'de 40.000 çadırlık bir Nogay topluluğunu itaat altına almalarıdır. Bundan sonra, Kalmukların Nogaylar üzerindeki baskısı giderek artmıştır. Nogaylar, bu baskıyı kırmak için 1644'te Kırım Hanlığından ve Çerkezlerden aldıkları destek ile Kalmuklar üzerine yürümüş ve onları ağır bir yenilgiye uğratmıştır. Ancak bu galibiyet Nogaylara kısa süreli bağımsızıktan başka bir şey getirmemiş, Nogaylar Kalmuk baskısından kurtulamamış ve parçalar halinde batıya göç etmeye başlamışlardır. ${ }^{74}$ Bu göç, Nogaylar için hayatı zorlaştırmıştır. Nitekim 1649'da Kırım Giray Sultan'dan Rus Çarına gönderilen bir mektupta Kalmuk akınlarının Nogayları darmadağın ve perişan bir hale getirdiği anlatılmaktadır. Burada bahsedilen Nogaylar Kuban Boyunun doğusundaki topraklarda yaşayan gruplardır. ${ }^{75}$ Kuban Boyunun orta ve batı kısmında oturan Nogayların, Kırım Hanlığından ve bazı Çerkez boylarından yardım aldıkları için daha

\footnotetext{
${ }^{71}$ Evliya Çelebi, a.g.e., s. 267-271.

${ }^{72}$ Alpargu, a.g.e., s. 44, 59, 60.

${ }^{73}$ Xavier Hommaire de Hell, Travels in the Steppes of the Caspian Sea, The Crimea, The Caucasus, London 1847, s. 224; Kalmukların İtil Boyu'na gelişlerine dair bkz. Oktay Berber, a.g.m., s. 365-368; Alper Başer, "Evliya Çelebi Seyahatnamesi'nde Nogaylar", Türk Dünyası Incelemeleri Dergisi, XI/2, 2011, s. 124.

${ }^{74}$ Berber, a.g.m., s. 369: Alpargu, a.g.e., s. 105.

${ }^{75}$ V. V. Velyaminov-Zernov, Kırım Yurtına ve OI Taraflarga Dair Bolgan Yarlıglar ve Hatlar, Haz. Melek Özyetgin-ilyas Kamalov, Ankara 2009, s. 423.
}

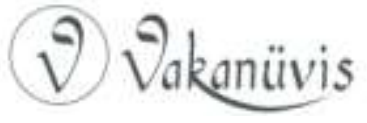


iyi durumda oldukları söylenebilir. Mesela Kasayoğlu ${ }^{76}$ Nogaylarından Nevruz Mirza, Kuban Boyu'nda kendine ait müstahkem bir mevkide yaşamaktadır. ${ }^{77} \mathrm{Bu}$ müstahkem mevkii Hatukay topraklarında bulunmaktadır ve Kırım Hanı III. İslam Giray ${ }^{78}$ tarafından Nevruz Mirza Nogaylarının Kalmuk saldırılarına karşı korunmaları için inşa edilmiştir. III. İslam Giray, Çoban Mirza Nogaylarına da benzer bir destek sunmuştur. O, Çoban Mirza için Çoban Kalesi adı verilen bir kale inşa ettirmiştir. Çoban Mirza aynı zamanda Çerkezlerden de yardım görmüş, hatta onlarla evlilik yoluyla akrabalık kurmuş ve tebaasının bir kısmı onların topraklarına yerleşmiştir. Onların yaşadıkları bölge kısa sürede mirzalarının adına atfen Çobaneli adıyla anılmaya başlanmıştır. Deveyeli Nogayları ise Âdemî ve Bolatkay Çerkezleri tarafından desteklenmiştir. ${ }^{79}$

1669'da Kalmukların başına geçen Ayuki, yeni bir kitlesel Nogay göçünü başlatmıştır. Ayuki'nin askeri faaliyetlere hız vermesi neticesinde 1670'de Yedisan Nogaylarının bir bölümü Kuban taraflarına gelmiştir. Ertesi yıl Süyünç Mirza önderliğindeki Nogaylar Kuzey Kafkasya'ya göç etmiş, bunları da bir başka Nogay grubu takip etmiştir. Ayuki, Nogaylar üzerindeki hakimiyetini kaybetmeye başlayınca Kuban taraflarına art arda akınlar düzenlemiş ve buraya yerleşmiş olan Nogayların bir kısmını tekrar İtil Boyuna götürmüştür. ${ }^{80}$

Ayuki'yi kontrol altında tutmak isteyen Rus yönetimi 1673'te onunla bir anlaşma imzalamıştır. Aslında bu anlaşma Rusya'nın güney sınırlarındaki düşmanlarına karşı yapılan bir ittifak niteliğindedir. ${ }^{81}$ Rus yönetiminin bu tarz anlaşmaları sürekli yenilediği, Ayuki'nin 1697-1698 yıllarında Kuban taraflarına gerçekleştirdiği saldırılardan anlaşılmaktadır. Bu tarihlerde Ruslar, Osmanlı Devleti'nin elinde bulunan Azak Kalesini ele geçirirken Ayuki de Kuban taraflarında çok sayıda Nogay'ı kılıçtan geçirmiştir. ${ }^{82}$ Bu olay İtil Boyundaki Nogaylar

\footnotetext{
${ }^{76}$ Bunlara Mansuroğlu da denilmektedir. (P. S. Pallas, Travels through The Russian Empire in the Years 1793 and 1794, Vol. II, London 1812, s. 424)

${ }^{77}$ Derin, a.g.t., s. 376.

78 1644-1654 yılları arasında hüküm sürmüştür.

${ }^{79}$ Evliya Çelebi, a.g.e., s. 270, 278, 285.

${ }^{80}$ Alpargu, a.g.e., s. 112-113.

${ }^{81}$ Berber, a.g.m., s. 368.

${ }^{82}$ Alpargu, a.g.e., s. 115.
}

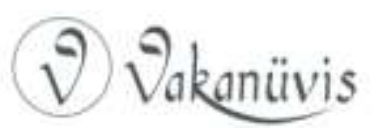


arasında dehşetle karşılanmış olmalıdır. Çünkü Ayuki'nin Kuban harekâtından hemen sonra, İtil Boyundaki yaklaşık 50.000 Nogay, Kalmuk topraklarını terk etmek için harekete geçmiştir. Bunlar, Kalmuklardan kurtulmak için Kırım hanından yardım istemişlerdir. Kırım hanı 5.000 kişilik bir kuvveti itil Boyuna göndermiştir. Ayuki, gelen kuvvetlerin azlığını küçümseyerek kendi kuvvetlerini 4.000'er kişilik gruplara bölmüş ve bu kuvvetleri göç için harekete geçen Nogaylar üzerine sevk etmiştir. Ayuki'nin bu stratejik hatası onun yenilgiye uğramasına neden olmuştur. Bu yenilgide Kırım kuvvetlerinin ateşli silahları kullanmasının etkisi olduğu kadar Nogayların içinde bulundukları psikolojik durum da önemli bir rol oynamıştır. Kalmuk baskısından bıkan Nogaylar "öldüklerine ve dirildiklerine bakmayub" bütün güçleri ile Kalmuklara saldırmışlardır. Bu hadiseyi duyan bölgedeki diğer Nogaylar da yine Kırım kuvvetlerinin yardımı ile Kuban bölgesine gelmeyi başarmıştır. Göç eden Nogaylar, Yedisan ve Camboyluk Nogaylarıdır ve başlarında Togan Mirza ile Sultan Murad Mirza bulunmaktadır. ${ }^{83}$

İtil Boyundan gelen bu Nogay aşiretleri Taman Yarımadası'nda bulunan Muntenâ Adasına yerleştirilmiştir. ${ }^{84}$ Esasında Osmanlı yönetimi, Nogayların iskânını Kırım Hanlığının bir iç meselesi olarak değerlendirmekte ve bu konuya mümkün olduğunca müdahale etmemektedir. ${ }^{85}$ Ancak Nogayların Muntenâ Adasına iskânlarında Osmanlı yönetimi meseleye dâhil olmuştur. Bunun nedeni 20 Şubat 1714'te İstanbul'dan Acu Kalesi Muhafızına gönderilen bir emirde açıkça ortaya konmuştur. Emirde, Acu Kalesi'nin ve Azak'a giden yolların güvenliği için Nogaylardan Orak Mirza'nın Acu Kalesi etrafına iskan edilmesi istenmektedir. ${ }^{86}$ Anlaşılacağı üzere güvenlik meselesi söz konusu olduğunda Osmanlı yönetimi olaylara müdahale edebilmektedir. Ancak bu hadisede dikkat edilmesi gereken başka bir

\footnotetext{
${ }^{83}$ Râşid, Târîh-i Râşid..., C. I, s. 538; Silâhdar Fındıklılı Mehmed Ağa, Nusretnâme, Sadeleştiren İsmet Parmaksızoğlu, C. I/II, İstanbul 1963, s. 251-253; Seyyid Muhammed Riza, a.g.e., s. 244-246.

84 Defterdar Sarı Mehmed Paşa, Zübde-i Vekayiât, Haz. Abdülkadir Özcan, Ankara 1995, s. 613; Silâhdar Fındıklılı Mehmed Ağa, Nusretnâme, C. I/II, s. 253; Râşid, Târîh-i Râşid..., C. I, s. 538.

${ }^{85}$ BOA. MD. 131, h. 1057.

${ }^{86}$ BOA. MD. 122, h. 388.
}

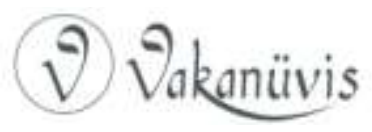


hususiyet bulunmaktadır. Orak Mirza, Kuban taraflarında otururken 1702 veya 1703 yılında tebaası ile birlikte o sıralarda Rusların egemenliğinde olan Azak'a gitmiş ve Azak hâkiminden himaye ve toprak talep etmiştir. İsteği kabul edilmeyince de Azak taraflarını yağmalayıp eski yurduna geri dönmüştür. ${ }^{87}$ Peki, Osmanlı Devleti sadakatinde şüphe uyandıracak bir topluluğa sınır bölgesinin güvenliğini neden emanet etmiştir? Bu sorunun cevabı Nogayların içinde bulunduğu siyasi-iktisadi koşullarda ve Osmanlı Devleti'nin yönetim anlayışında yatmaktadır.

Kırım Giray Sultan, Rus Çarına gönderdiği 1649 tarihli mektubunda Kalmukları "rüzgâr gibi gelüb geçer bir hırsız haramzâde" taifesi olarak tanımlamaktadır. ${ }^{88}$ XVIII. yüzyıl tarihçilerinden Seyyid Muhammed Rıza ise saldırı halindeki Kalmuk askerleri için "ebr-i siyâh-ı tufan" benzetmesini yapmaktadır. ${ }^{89} \mathrm{Bu}$ tanımlamalar Kalmukların askeri güçlerini ve karşı tarafta bıraktığı etkiyi ortaya koymaktadır. Kalmuklar, gerçekten de XVII. yüzyıldan itibaren Kuban Boyuna düzenledikleri akınlarla korkuya ve paniğe yol açmışlardır. Ancak bundan da önemlisi akınlarıyla bölgeyi siyasi ve iktisadi açıdan istikrarsız bir hale getirmelidir. Bu koşullar altında Nogayların yaşamlarını sürdürmeleri için birkaç çıkar yolu kalmıştır. Onlar ya daha istikrarlı ve güvenli bölgelere yeniden göç etmek zorunda kalacaklardır ${ }^{90}$ ya da giderek yoksullaştıkları için yerleşik hayata geçeceklerdir veyahut da hamilerine daha iyi şartlar sunmaları için isyan edeceklerdir. Orak Mirza'nın göçü birinci duruma bir örnektir. Osmanlı Devleti'nin Orak Mirza'ya güven duyması onun ve tebaasının içinde bulunduğu şartları yakinen bilmesinden ileri gelmiş gibi görünmektedir. Kuban Boyunda oturan Yedikçioğlu Nogaylarından 3.000 hanelik bir grubun $1725^{\prime}$ ten önce Kırım hanına başvurarak Özi taraflarına göç etmesi bu durumun bir başka örneğini oluşturmaktadır. ${ }^{91}$

\footnotetext{
${ }^{87}$ BOA. MD. 114/1, h. 3.

${ }^{88}$ Velyaminov-Zernov, a.g.e., s. 424.

${ }^{89}$ Seyyid Muhammed Rıza, a.g.e., s. 273.

90 Başer, "Evliya Çelebi...", s. 119.

${ }^{91}$ BOA. MD. 133, h. 550; Kırım Hanlarına Nâme-i Hümâyûn (2 Numaralı Name Defteri), s. 177.
}

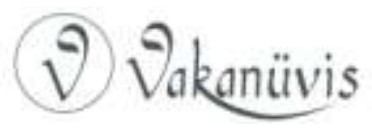


Elbette ki, Kuban Boyunda istikrarsızlığa yol açanlar sadece Kalmuklar değildir. Ten Kazaklarının, Rusların ve Rusların desteğini alan Gürcülerin de zaman zaman bölgeye saldırıları ve müdahaleleri olmuştur. ${ }^{92}$ Osmanlı Devleti ve Kırım hanları bu saldırılara karşı tedbir amaçlı Kuban Boyunda ve Çerkez topraklarında bir dizi kale inşa ettirmiş, kalelerin etrafına da Nogay göçmenlerini yerleştirmiştir. Ayrıca, kaleler Osmanlı askeriyle de desteklenmiştir. Bu suretle bölgenin güvenliği sağlanmaya çalışılmış ve İtil'den gelen Nogaylara da arazi tahsis edilmiştir. ${ }^{93}$

Kuban Boyunun güneybatısındaki dağılık alanlarda yaşayan Abhazların da özellikle Karadeniz kıyısındaki yerleşim yerlerine zaman zaman akın tertip ettikleri görülmektedir. Ancak bunların amaçları gündelik hayatta intiyaç duydukları eşyaları ya da tuz gibi temel gereksinim maddelerini karşılamaya yöneliktir ve bu yüzden akınları Kalmukların ya da Kazaklarınki gibi büyük tahribata ya da bölgenin etnik haritasının değişmesine yol açmamaktadır. ${ }^{94}$

Kırım hanlarının tutumu, hanzâde ve şirin beylerinin isyanları bölgedeki istikrarsızlığın diğer nedenleridir. Kırım hanlarının ekonomik koşullar zorlaştığında Çerkezlerden aldığı vergiyi arttırması Çerkezler arasında hoşnutsuzluğa, hatta isyana sebep olmaktadır. Bu gibi durumlarda Kırım kuvvetlerinin uzun süreli ve yoksulluk getiren Kafkasya seferleri başlamaktadır. Mesela 1707 'den önce verginin arttırılmasından dolayı başlayan Çerkez isyanı dalgalar halinde 1729'a kadar sürmüştür. Kırım kuvvetleri Kuzey Kafkasya'ya girdiklerinde isyan halindeki Çerkezlerin bölgelerini terk ettikleri bilinmektedir. Buna ilaveten seferlere katılmak zorunda kalan Nogaylar da seferlerin getirdiği olumsuz koşullardan etkilenmektedirler. ${ }^{95}$

\footnotetext{
${ }^{92}$ Ahmed Cavid Bey, a.g.e., s. 192; BOA. MD. 130, h. 1240; Berber, a.g.m., s. 370; Subhî Mehmed Efendi, a.g.e., s. 283; Yılmaz Nevruz, Umûmî Kafkas Tarihine Giriş, C. II, İstanbul 2016, s. 269.

${ }^{93}$ Alan Fisher, Kırım Tatarları, İstanbul 2009, s. 44; BOA. MD. 110, h. 1918.

${ }^{94}$ BOA. MD. 134, h. 726.

${ }^{95}$ Saîd Giray, a.g.e., vr. 144a; Silâhdar Fındıklılı Mehmed Ağa, Nusretnâme, C. II/II, s. 247; Seyyid Muhammed Rıza, a.g.e., s. 312; Klaproth, a.g.e., s. 191-192; Hammer, a.g.e., s. 134-135.
}

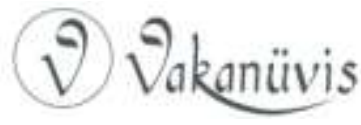


Hanzâde ve şirin beylerinin isyanlarının etkilerine gelince; Hana karşı isyan eden bu kişiler kendilerine taraftar bulmak ya da daha iyi bir şekilde kendilerini savunabilmek için Bucak veya Kafkasya taraflarına geçmekte ve buralarda yaşayan halkları kendi taraflarına çekmektedirler. Mesela 1720'de şirin beylerinden Hacı Can Temür, hana karşı isyan ettiğinde Kuban taraflarına geçmiş ve uzun bir süre bu bölgede saklanmıştır. Hacı Can Temür, 1727 'de II. Mengli Giray'a isyan eden Baht Giray ile ittifak kurmuştur. Bu ikisi Yedisan, Canboyluk ve Yediçkul Nogaylarından bazı grupları kendi taraflarına çekmişlerdir. Hacı Can Temür ve Baht Giray aynı zamanda Çerkezlerden de yardım almışlardır. Öte yandan Baht Giray, Kalmukların desteğini sağlamak için onlarla temasa geçmiş ve onlara, eski tebaası olan Nogayları verme vaadinde bulunmuştur. Baht Giray daha sonra han taraftarı olan Nureddin Mirzayı, Kasayoğlu Mirzasını ve Kaspolatoğlu Mirzasını öldürtmüş, bunların mallarını yağmalamıştır. İsyanı bastırmak için bölgeye gelen Kırım kuvvetleri ise isyancıları destekleyen ovaları kılıçtan geçirmiştir. İsyanın ilerleyen günlerinde Nogaylar, Baht Giray ile Kalmuklar arasındaki anlaşmayı duymuşlar ve ona destek vermeyi bırakmışlardır. Nogaylar, Kırım hanına başvurarak af dilemişler ve kendilerinin bir başka bölgeye nakledilmelerini istemişlerdir. Bunun üzerine Kırım hanı göç etmek isteyen Nogayları Kııım taraflarına yerleştirmiştir. ${ }^{96}$

İstikrarsız bir ortamda Nogaylar için göç etme dışında yerleşik hayata geçme ya da isyan etme ${ }^{97}$ gibi seçeneklerin de bulunduğu az önce belirtilmişti. Göçebe toplumlar için yerleşik hayata geçme göçebe ekonomisinin istikrarsızlığının bir sonucudur. ${ }^{98}$ Kalmukların, Kazakların ya da başka toplulukların saldırılarına maruz kalan ve neredeyse devamlı göç halinde olan Nogaylar, iktisadi açıdan zayıflamaya, bunun

\footnotetext{
${ }^{96}$ Smirnov, a.g.e., s. 210, 474-477; Râşid, Târîh-i Râşid..., C. III, s. 1602-1603; Seyyid Muhammed Riza, a.g.e., s. 317-318; 334; Hammer, a.g.e., s. 137, 140-141; Howorth, a.g.e., s. 575; Uzunçarşılı, a.g.e., s. 13.

971706 yılında Anapa civarında oturan Nogayların isyanı, Baht Giray İsyanı sırasında bazı Nogay gruplarının isyana destek vermeleri, Nogayların üçüncü seçeneği için örnek teşkil eder. (Alpargu, a.g.e., s. 116; Howorth, a.g.e., s. 571)

${ }^{98}$ Anatoly M. Khazanov, Göçebe ve Dış Dünya, Çev. Ömer Suveren, İstanbul 2015, s. 179.
} 
sonucunda da yerleşik hayata geçmeye başlamışlardır. ${ }^{99}$ Kalmuk tehdidinden kaçıp Kuban Boyuna gelen ve tarımla uğraşan İşterekoğlu Kabilesi bu olgu için iyi bir örnek teşkil eder. ${ }^{100}$ Bir başka örnek, Kuban Boyu'nda otururken Kırım taraflarına göç eden Kasayoğlu ve Kaspolatoğlu aşiretlerinden yaklaşık 4-5 bin hanelik büyük bir Nogay topluluğudur. Bunlar, II. Selim Giray zamanında Kırım'daki harap köylere iskan olunmuşlar ve bu köylerin mamur hale gelmesini sağlamışlardır. Bunların göç etme nedenleri ekonomik zorluklar, mirzalarının kötü yönetimi ve Kazakların baskılarıdır. Bu göç eden topluluk içerisinde Çerkezlerin de bulunması, Nogayların Çerkezlerle olan akrabalıklarından ileri gelmiş olabilir. ${ }^{101}$ Burada akrabalık bağları Çerkezlere yarar sağlamıştır. 1736 'da başlarında Dondok Ombo'nun bulunduğu Rus destekli Kalmuk kuvvetlerinin Kuban Boyuna düzenledikleri akında ise akrabalık bağı Nogayların lehine işlemiştir. ${ }^{102}$ Kalmuklar, Nogayları Astrahan tarafına göçürmek istediklerinde Çerkezler, Nevruz Mirza Nogayları ile olan akrabalıklarından dolayı onlara sahip çıkmış, bu yüzden Nevruz Mirza Nogayları göçürülmekten kurtulmuştur. ${ }^{103}$ Ancak yaklaşık 10.000 Nogay için aynı durum geçerli değildir. Bunlar Kalmuklara esir düşmüşler ve Astrahan taraflarına götürülmüşlerdir. ${ }^{104}$

Kazaklar, XVIII. yüzyılın ilk yarısında, azınlıkta olsalar da, Kuban Boyundaki üçüncü önemli etnik grup olarak değerlendirilebilirler. Kuban taraflarına ilk Kazak göçü, 1689'da Don Kazaklarının merkezi konumundaki Zapolyansk şehrinin Ruslar tarafından tahrip edilmesiyle gerçekleşmiştir. ${ }^{105}$ Bu ilk Kazak grubu yaklaşık 300 kişidir ve bunlar Acu

\footnotetext{
${ }^{99}$ Alpargu, a.g.e., s. 116-117.

${ }^{100}$ BOA. MD. 114/1, h. 2299; BOA. MD. 114, h. 695.

${ }^{101}$ Saîd Giray, a.g.e., vr. 105a, 105b.

102 Berber, a.g.m., s. 370.

${ }^{103}$ Derin, a.g.t., s. 537-538.

104 Brian J. Boeck, Imperial Boundaries Cossacks Communities and Empire-Building in the Age of Peter the Great, New York 2009, s. 232.

105 Osman Bayramaliyev, "Rus tarihçi Sen, Don kozakları ile Kırım Hanlığı arasındaki gerçek ilişkileri anlatacak", 18 Temmuz 2011, http://qha.com.ua/tr/savasguvenlik/rus-tarihci-sen-don-kozaklari-ile-kirim-hanligi-arasindaki-gercek-iliskileri-

anlatacak/96625/, Erişim tarihi: 22.04.2017 (Dr. Dmitriy Sen'in “Don ve Kuzeybatı Kafkasya Kozaklarının 17. Yüzyılın 2. Yarısı-18. Yüzyılın Başında Karadeniz Bölgesi Müslüman Ülkeleriyle İlişkileri" isimli kitabının tanıtım yazısıdır.)
}

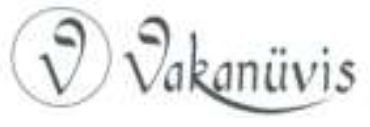


Kalesi yakınlarındaki Kapulu isimli mahalle yerleştirilmiştir. Daha sonraki yıllarda İtil Boyundan gelen Yedisan Nogaylarının bölgeye iskan edilmesiyle burada rahat edemeyen Kazaklar, Anapa ile Poçgur Nehirleri arasında, Han Tepesi denilen yerin yakınlarına göç etmişlerdir. 1707'de başlayan Bulavin İsyanı, Kuban Boyuna ikinci Kazak göçünü başlatmıştır. İsyan, I. Petro tarafından sert bir şekilde bastırılınca Bulavin'in en önemli yardımcılarından birisi olan İgnat Nekrasov, kendisine tabi olan yaklaşık 3.000 kişiyle birlikte Kırım Hanlığına iltica etmiştir. İgnat ve tebaası, Anapa ile Poçgur Nehirleri arasına iskan olunmuşlardır. Zamanla bölgeye gelenlerin sayısı artmış ve bölgedeki Kazak nüfusu 10.000'i aşmıştır. ${ }^{106}$ Kuban Boyunda yaşayan Kazaklar, $\mathrm{Hal}^{107}$, Celali $^{108}$, Ağnat ${ }^{109}$, Inat ${ }^{110}$ ve Nekrasov Kazakları ${ }^{111}$ isimleriyle anılmaktadırlar.

Kuban Kazakları, bölgedeki Nogaylarla birlikte Don Bölgesine akınlar düzenlemişlerdir. İgnat Nekrasov'un, Kazaklar hakkındaki her şeyi bilmesi bu akınlarda Nogaylara büyük yarar sağlamıştır. Fakat Kuban Kazakları, inançlarından dolayı I. Anna'nın baskısına maruz kalmıştır. Bunların bir kısmı 1740-41 yıllarında Trabzon, Samsun ve Tuna taraflarına göç etmiş, diğerleri ise aynı bölgede oturmaya devam etmiştir. ${ }^{112}$

Kuban Boyunun sürekli değişen bir etnik çehresi bulunmaktadır. Bununla birlikte bölgedeki grupları ve bunların yerleştikleri sahayı az çok belirlemek mümkündür. Kuban Nehri'nin kuzeyindeki saha, Taman yarımadası haricinde, XVIII. yüzyıldaki göçlerle Nogay yurdu haline gelmiştir. Yediçkul, Camboyluk, Nevruzoğulları, Yedisan, Akkerman, Kasayoğlu, Kaspolat ve Mangıt, Kuban Nehri'nin kuzeyinde Karadeniz'den Büyük Kabardey topraklarına kadar uzanan sahada

\footnotetext{
106 Öztürk, “Osmanlı Karadenizi...", s. 83, 88; Hammer, a.g.e., s. 136.

${ }^{107}$ BOA. MD. 133, h. 885.

${ }^{108}$ BOA. MD. 142, h. 1113; Derin, a.g.t., s. 434.

${ }^{109}$ Derin, a.g.t., s. 434.

${ }^{110}$ Hammer, a.g.e., s. 136.

111 Thomas M. Barrett, At The Edge of Empire: The Cossacks and the North Caucasus Frontier, 1700-1860, Colorado 1999, s. 43.

112 Boeck, a.g.e., s. 232-233, 241; Barrett, a.g.e., s. 174.
}

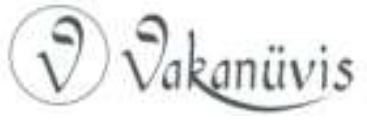


oturan başlıca Nogay gruplarıdır. ${ }^{113}$ Bu grupların Sultan Mahmudoğlu, Çitçegioğlu, İşterekoğlu, Kıtay-Kıpçak, Yaman Sadak, Orakoğlu, Arslan Bey gibi alt grupları bulunmaktadır. ${ }^{114}$ Taman Yarımadası ise eskisi gibi kozmopolit bir yapı sergilemektedir. Bununla birlikte, Osmanlı yönetiminin bölgedeki bazı sancakların idaresini Çerkezlere bırakması, buradaki Çerkez nüfusunun fazlalığına işaret etmektedir. ${ }^{115}$ Çerkezlerin yoğun olarak yaşadıkları yerler ise Kuban Nehri'nin güneyinde kalan sahadır. Ancak bu sahada, sayıları bazen on binleri bulan Nogay gruplarının da yaşadığını belirtmek gerekir. Osmanlı Türkleri ve Kazaklar bölgenin batısında yaşamaktadırlar. Kuban Nehri'nin kaynağına doğru, tarihi süreç içerisinde bölgeye gelen farklı Türk topluluklarından teşekkül etmiş olan Karaçay-Malkar Türkleri bulunmaktadır. ${ }^{116}$ Bunların XVIII. yüzyılın ilk yarısında Kuban Boyuyla olan ilişkilerine dair net bilgiler mevcut değildir. Fakat XVIII. yüzyılın sonlarına doğru Karaçay-Malkar coğrafyasında bazı Nogay yerleşim yerlerinin bulunması, Karaçay-Malkarlar ile Nogaylar arasındaki ilişkilere dair bir ipucu vermektedir. ${ }^{117}$

\section{iktisat}

Kuban Boyunda, iktisadi hayatın temelini hayvancılık oluşturmaktadır. Bu durum hem Nogaylar hem de Çerkezler için geçerlidir ve her iki toplum da farklı hayvan türlerinin bulunduğu karma sürülere sahiptir. Bu farklılık göçebe toplumlarda meraların daha verimli kullanılmasına ve sürünün daha sağlıklı ve istikrarlı olmasına imkan verir. ${ }^{118}$ Sürülerde hangi hayvan türlerinin bulunacağını belirleyen ise büyük ölçüde Kuban Boyunun fiziki ve beşeri özellikleri olmuştur. Mesela Kuban Nehri'nin kuzeyindeki Deşt-i

\footnotetext{
${ }^{113}$ George Ellis, Memoir of a Map of the Countries Comprehended between the Black Sea and Caspian with an Account of the Caucasian Nations, London 1788, s. 16; Nevruz, a.g.e., s. 224; Râşid, Târîh-i Râşid..., C. III, s. 1602; Pallas, a.g.e., s. 422-424.

114 Seyyid Muhammed Rıza, a.g.e., s. 245, 266; Saîd Giray, a.g.e., vr. 111a; Öztürk, "Osmanlı Karadenizi...", s. 83; Râşid, Târîh-i Râşid..., C. I, s. 538; Smirnov, a.g.e., s. 462.

${ }^{115}$ BOA. MD. 155, h. 143; Sadık Müfit Bilge, Osmanlı Çağı'nda Kafkasya, İstanbul 2012, s. 383.

116 Malte Brun, a.g.e., s. 49. Karaçay Malkar Türkleri için bkz. Adilhan Adiloğlu, Karaçay-Malkar Türkleri, Ankara 2005.

${ }^{117}$ George Ellis, a.g.e., s. 16, 17.

${ }^{118}$ Khazanov, a.g.e., s. 109.
}

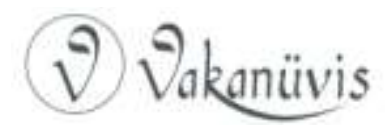


Kıpçak bozkırı ve nehrin güneyinde kalan düz araziler at ve koyun yetiştirmek için son derece elverişlidir. Buna karşlık, Taman Yarımadasındaki Kuban Nehri'nin karşısında yer alan dağlar, Kafkas dağlarının diğer bölgelerine göre daha sade ve ot ve su açısından daha zengindir. Bu yüzden bu bölgede büyük baş hayvan yetiştiriciliği ön plana çıkmaktadır. ${ }^{119}$ Kafkas dağlarının yüksek rakımlı kesimleri ise keçi yetiştirmek için elverişli bir coğrafyadır. ${ }^{120}$

At, Nogayların sürülerindeki en önemli hayvandır. Nogaylar, Türk ve Arap atlarının melezleşmesiyle elde edilmiş olan ve "argamak" denilen bir at türüne sahiptir. Bunlar, özel bir eğitimin ardından uzun süre susuzluğa ve açlığa dayanabilmektedirler. Bu yüzden savaşta binicilerine büyük kolaylık sağlamakta, taşıdığı bu özellikler nedeniyle pazarlarda yüksek fiyatlarla alıcı bulabilmektedirler. ${ }^{121}$ Kafkas dağlarının yüksek kesimlerinde oturan Karaçay-Malkarların yetiştirdikleri atlar da estetik görünümleri, bacaklarının sağlamlığı, hızı, dayanıklılı̆ı, uysallığı ve zeki oluşlarıyla ünlenmiştirler. Bunlar Osmanlı topraklarında, Rusya'da ve İran'da yüksek fiyatlarla satılmaktadırlar. ${ }^{122}$

Çerkez atları da Nogay atları gibi özelliklere sahiptirler ve bu özelliklerinden dolayı pazarlarda büyük rağbet görürler. ${ }^{123}$ Bununla birlikte Çerkez atlarını Nogay atlarından ayrılan özellikleri de bulunmaktadır. Mesela Çerkezlerin "şağdiy" dedikleri bir at türü Kafkas Dağlarının sarp coğrafyasında kolaylıkla ilerleyebilirler. Isı değişimlerine dayanaklıdırlar. Karanlıkta ya da sisli havalarda yolunu kaybetmezler. Ağır yükleri yorulmadan taşıyabilirler. Bunlar "uzun boyunlu, kalın gövdeli, kısa ve güçlü bacakları" olan atlardır. ${ }^{124}$

Nogaylar için at sadece bir savaş ya da ulaşım aracı değildir. At, onlar için aynı zamanda bir besin kaynağıdır. Atın etini yerler ve yaygın bir şekilde kısraktan elde ettikleri bir tür içecek olan kımızı tüketirler.

\footnotetext{
${ }^{119}$ Ahmed Cavid Bey, a.g.e., s. 269.

${ }^{120}$ Malte Brun, a.g.e., s. 31.

${ }^{121}$ Alpargu, a.g.e., s. 187-189.

${ }^{122}$ Edmund Spencer, a.g.e., s. 340.

${ }^{123}$ Zeynep Özdem, Kırım Karasubazar'da Sosyo-Ekonomik Hayat, Ankara 2010, s. 163; Tavernier, a.g.e., s. 313.

${ }^{124}$ Murat Papşu, "Çerkezlerde Atçılık ve At Kültürü", Nart, S. 72, Mart-Nisan 2010, s. 54.
}

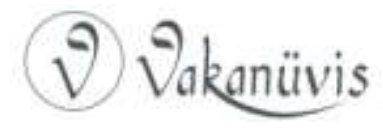


Tabii ki bu durum daha çok bozkırdaki göçer Nogaylar için geçerlidir. Bozkırda yaşayan Nogayların menüleri kısıtlı su imkanlarından ve yiyecek çeşitliliğin azlığından dolayı at etinden, kısrak sütünden ve koyunlardan elde edilen süt ürünlerinden oluşur. ${ }^{125}$ Yarı göçer ya da yerleşik Nogaylarda beslenmede et ve süt ürünlerinin yanında hububatın da önemli bir yeri vardır. Nitekim bu Nogayların ana menülerinde yer alan "talkan" kavrulmuş arpa unundan, "lakşa" ise undan yapılmaktadır. ${ }^{126}$ Astrahan civarında oturan Nogayların ana menüsü ise balık ve pirinçten oluşmaktadır. ${ }^{127}$ Kış aylarında konaklamak için Kuban Nehri yakınlarına gelen Nogayların da burada avladıkları balığı suda kaynatıp tükettikleri bilinmektedir. ${ }^{128}$

At etinin beslenme dışında tedavi amaçlı kullanımı da söz konusudur. At eti diğer hayvanların etine göre daha fazla kaloriye, minerale ve aminoaside sahip olduğundan, ayrıca $A$ ve $B$ vitaminlerini içerdiğinden yüksek bir tedavi gücüne sahiptir. ${ }^{129}$ Bu yüzden Nogaylar, yaraların tedavisinde at etini kullanmaktadırlar. ${ }^{130}$

Atlar, yaklaşık $40-50 \mathrm{~cm}$ karın altındaki otlara ulaşabilen bir hayvan olduğundan sert geçen kış aylarında beslenmeleri sorun teşkil etmez. Bu özellikleriyle Nogayların gelecek yıla ulaşmalarına imkân verirler. Atların Nogaylara sunduğu bu geniş imkânlar Nogayların atlar konusunda uzmanlaşmasını sağlamıştır. Mesela bir Nogay genci, bahar ayında bozkıra salınan ve neredeyse yabanileşmiş hale gelmiş olan yılkılardan istedikleri atları kolaylıkla yakalayabilir, atı yakalamadan atın binek atı mı yoksa arabaya koşulacak at mı olduğunu anlayabilir. ${ }^{131}$ Bu konuda Çerkezler de ustalaşmışlardır. Çerkezler yabani atları yakalamak için bazı atları özel olarak yetiştirirler. Bu ata "arkançeş" adı

\footnotetext{
${ }^{125}$ Tavernier, a.g.e., s. 323, 325.

${ }^{126}$ Evliya Çelebi, a.g.e., s. 271.

127 Jan Janszoon Struys, The Perillous and Most Unhappy Voyages of John Struys through Italy, Greece, Lifeland, Muscovia, Tartary, Media, Persia, East-India, Japan, and other Places in Europe, Africa and Asia, London 1694, https://quod.lib.umich.edu/e/eebo/A61855.0001.001/1:9.5?rgn=div2;view=fulltext;q1 =adam+olearius, Erişim Tarihi: 08.04.2017.

${ }^{128}$ Tavernier, a.g.e., s. 326.

${ }^{129}$ Khazanov, a.g.e., s. 142.

${ }^{130}$ Alpargu, a.g.e., s. 208.

${ }^{131}$ Baron de Tott, Türkler ve Tatarlara Dair Hâtıralar, Çev. Mehmet R. Uzmen, İstanbul ts, s. 109.
} 
verilmektedir. Anadolu ve Rumeli'ndeki Atçeken Ulusu'nun bir benzeri Çerkezlerde de bulunmaktadır. Önemli bir Çerkez boyu olan Şapsuğ’un kelime anlamı "at yetiştiricileri"dir. ${ }^{132}$ Aslında Çerkezcede atlarla ilgili mevcut çok sayıda terim ve deyimin bulunması, Çerkezler için atın önemini ve Çerkezlerin bu konudaki uzmanlığını ortaya koymak için yeterli bir delil olarak kabul edilebilir. ${ }^{133}$

Çerkezler de tıpkı Nogaylar gibi atı ulaşımda, savaşta ve ticari değiş tokuşlarda kullanırlar. Bununla birlikte bazı Çerkez toplulukları dışında Çerkezlerde atın beslenmede pek yeri yoktur. Çerkezlerin çoğunluğu koyun ve sığır ile geyik gibi av hayvanlarının etlerini tüketirler. ${ }^{134}$ Ancak kısrak sütünü Nogaylar gibi yoğun bir şekilde tükettiklerini belirtmek gerekir. ${ }^{135}$ Bunun dışında onların menüsünde darıdan yapılan bir tür ekmek, süt ürünleri ve bal bulunmaktadır. ${ }^{136}$ Bu sonuncu ürün doğanın vermiş olduğu bir hediye olarak değerlendirilir. Özellikle iki farklı bal türü, Kafkasya'nın endemik bitkilerinden kaynaklanan tatlarıyla ilkçağdan itibaren büyük bir şöhrete sahiptir. ${ }^{137}$

Attan sonra ikinci sırada koyun gelmektedir. Koyun, farklı bitkilere gerek duymadan beslenebildiğinden bozkırda tercih edilen bir hayvan türüdür. ${ }^{138}$ Nogaylar bunların etinden, sütünden, yününden ve derisinden istifade etmektedirler. Bunlardan elde ettikleri yağı Taman'a getirip satarlar. XVII. yüzyılda Kalmuk akınlarının Nogaylara verdiği zarar nedeniyle Taman'a gelen yağ miktarında azalma görülmüş, bu ise İstanbul'da yağ fiyatlarının artmasına neden olmuştur. ${ }^{139}$ Çerkezler ise hem koyun hem de keçi sürülerine sahiptirler. Çerkezlerin koyunlardan elde ettikleri yünün kalitesi oldukça yüksektir. Bu yünler Moskova'daki imalathanelerde keçe

\footnotetext{
${ }^{132}$ Tavkul, a.g.e., İstanbul 2007, s. 133.

${ }^{133}$ Bu terminoloji için bkz. Murat Papşu, a.g.m., s. 55-56.

${ }^{134}$ A. De La Motraye, a.g.e., s. 76.

135 Reineggs and Marshal Bieberstein, A General, Historical and Topographical Description of Mount Caucasus, V. I, Translated Charles Wilkinson, London 1807, s. 289.

${ }^{136}$ Reineggs, a.g.e., s. 289; Evliya Çelebi, a.g.e., s. 277, 289; Âşık Mehmed, a.g.e., s. 1101; Jean Chardin, Chardin Seyahatnamesi, Çev. Ayşe Meral, Ed. Stefanos Yerasimos, İstanbul 2014, s. 107.

${ }^{137}$ Edmund Spencer, a.g.e., s. 339; Malte Brun, a.g.e., s. 39.

${ }^{138}$ Alpargu, a.g.e., s. 189; Khazanov, a.g.e., s. 134.

${ }^{139}$ Alpargu, a.g.e., s. 190-191.
}

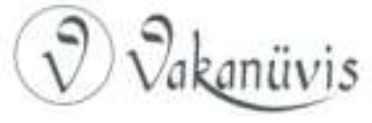


yapımında kullanılmak üzere bölgeye gelen Rus tüccarlara tarafından satın alınır. Buna ilaveten Çerkezlerin Nogaylar gibi Taman'ın önemli bir yağ tedarikçisi olduğu söylenebilir. ${ }^{140}$

Büyük baş hayvanlara gelince; deve, hem göçer hem de yerleşik Nogaylar tarafından beslenen bir hayvandır. Göçer Nogaylar develeri yük taşımada, yerleşik Nogaylar ise çift sürmede kullanmaktadırlar. ${ }^{141}$ Çerkezler ise tarlalarını 6-7 öküzün çektiği sabanlarla sürmektedirler. Öte yandan Nogaylarla kıyaslandığında daha çok dağlık arazilerde bulundukları için Çerkezlerde deve, tercih edilebilecek bir hayvan olarak görülmemektedir. ${ }^{142}$

Inek ve öküzler daha çok Çerkezlerin besledikleri hayvanlardır. Taman Yarımadasının karşısında yer alan dağlarda oturan Çerkezler için inek beslemek bir avantajdır. Çünkü bu coğrafyanın imkanları en zayıf bir inekten bile günde en az 13-15 litre süt alınmasına olanak sağlamaktadır. ${ }^{143}$

Hayvancılık konusunda belirtilmesi gereken son nokta Kalmukların sahip olduğu sığır türüdür. Kalmuk sığırları yaz ve kış aylarında ahırlara kapatılma gereksinimi duyulmayan ve bozkırdan beslenebilen hayvanlardır. Bu özellikleri ile bozkırda yetiştirilmeye uygun olduğu ve XVIII. yüzyılda Don Kazakları arasında en fazla tercih edilen tür olduğu bilinmektedir. ${ }^{144}$ Kalmuklar, Kuban Boyu için yağmacı bir topluluk olarak değerlendirilebilir. Ancak bölge ile olan ilişkileri bu sığır tipini bölgeye taşımış olabilir.

Kuban Boyunda tarımsal üretim, bölgenin batı kısmında, özellikle Taman Yarımadasında yoğunlaşmaktadır. ${ }^{145}$ Bunun sebebi, elde edilen ürünlerin bölgede kolaylıkla pazarlanabilmesidir. Mesela Taman tahılı, bölgedeki Taman, Temrük gibi yerleşim yerlerinde tüketilebilmekte, yakınlardaki büyük bir tüketim merkezi olan Azak'a gönderilebilmekte ya da limanlar aracılığı ile Kırım'a ve İstanbul'a nakledilebilmektedir.

\footnotetext{
${ }^{140}$ Tavernier, a.g.e., s. 313.

${ }^{141}$ Alpargu, a.g.e., s. 192.

142 Malte Brun, a.g.e., s. 47.

143 Ahmed Cavid Bey, a.g.e., s. 269.

${ }^{144}$ Xavier Hommaire de Hell, e.g.e., s. 149.

145 Ömer Bıyık, Kırım'ın Idarî ve Sosyo-Ekonomik Tarihi, İstanbul 2014, s. 46, 202.
}

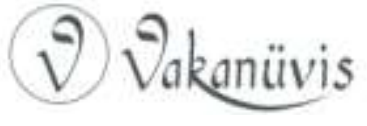


Bölgenin iç kesimlerindeki zirai üretimin boyutu tam olarak tespit edilememektedir. Bununla birlikte bölgedeki tarımsal üretim hakkında az çok bilgi bulunmaktadır. Buna göre Çerkezlerin darı, arpa, yulaf ve az miktarda buğday yetiştirdikleri bilinmektedir. Onlar arpayı atların beslenmesinde, darıyı ise ekmek yapımında kullanmaktadırlar. ${ }^{146} \mathrm{Bir}$ bölgenin verimini düşürmemek için o bölgeyi üst üste iki defa ekmezler, her yıl tarlalarını değiştirirler. ${ }^{147}$ Aslında Çerkezlerin tarımla çok fazla uğraşmalarını gerektirecek bir durum bulunmamaktadır. Çünkü tahıl dışındaki pek çok ürün tohum ekilmeden kendiliğinden yetişmektedir. ${ }^{148}$

Göçer Nogaylarda tarımın yapılması mümkün görünmemektedir. Ancak yarı göçebe ve yerleşik hayata geçmiş Nogaylar için tarım hayvancılık kadar yaygın bir uğraştır. Taman Yarımadasına yerleşen İşterekoğlu aşiretinin darı ektiklerinden daha önce bahsedilmişti. İşterekoğlu aşireti yerleşik Nogaylar için iyi bir örnektir. Yarı göçebe Nogaylardan ise Çoban Mirza Nogayları örnek gösterilebilir. Bunlar, sığırlardan daha güçlü olduğu için develerle çift sürmekte, darı, arpa ve buğday ekmektedirler. ${ }^{149}$ Elde ettikleri ürünün fazlasını ise kazmış oldukları çukurlara doldurmaktadırlar. Çukurlar daha sonra kapatılarak ürün gizlenmektedir. Bunu muhtemelen hayvanlarını otlatmak için bölgelerini terk ettiklerinde ürünlerinin yağmalanmasını önlemek amacıyla yapmaktadırlar. ${ }^{150}$ Çerkezler gibi Nogayların da aynı yeri üst üste iki defa ekmedikleri söylenebilir. ${ }^{151}$

Balıkçılık Kuban Boyunda önemli bir yere sahiptir. Balıkçılık Kuban Nehri'nin Azak Denizine ve Karadeniz'e dökülen kolları üzerinde yoğun bir şekilde yapılmaktadır. XVIII. yüzyıla kadar buralarda balıkçılık geleneksel yöntemlerle yapılmıştır. Ancak XVIII. yüzyılda Temrük ve Acu yakınlarında balık dalyanlarının kurulmasıyla balıkçııkta kısmen

\footnotetext{
${ }^{146}$ Reineggs, a.g.e., s. 289; Tavernier, a.g.e., s. 313; A. De La Motraye, a.g.e., s. 61; Âşık Mehmed, a.g.e., s. 1101.

${ }^{147}$ Tavernier, a.g.e., s. 313

${ }^{148}$ A. De La Motraye, a.g.e., s. 61; Tavernier, a.g.e., s. 313.

${ }^{149}$ Evliya Çelebi, a.g.e., s. 270, 271.

150 Jean Chardin, a.g.e., s. 104.

${ }^{151}$ Baron de Tott, a.g.e., 130.
}

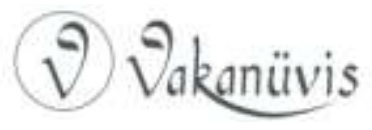


uzmanlaşmanın sağlandığı görülmektedir. ${ }^{152}$ Acu yakınlarındaki dalyanlardan yıllık 500 guruşdan fazla gelir elde edilir. Bu para Acu Mutasarrıfına tahsis edilmiştir. ${ }^{153}$ Temrük'teki dalyanlardan ise yıllık 3.000 guruşluk gelir elde edilir. 1740 yılında buradaki dalyanların işletme imtiyazı bir Çerkez beyine aitti. ${ }^{154}$ Esasında buradaki dalyanların Çerkezler tarafından işletilmesi normal bir durumdur. Çünkü Temrük'ün nüfusunun önemli bir kısmı Çerkezlerden oluşmaktadır ve burada oturanlar büyük ölçüde balıkçılıkla geçinmektedirler. ${ }^{155}$ Bir diğer balıkçı kasabası ise Karadeniz kıyısındaki Kızıltaş'tır. ${ }^{156}$

Çerkezler ve Nogaylar için balık hem bir besin maddesi ${ }^{157}$ hem de büyük karlar sağlayan ticari bir emtiadır. Kuban nehrinden akbalık, sevrek balığı, morina ve mersin balıkları yakalanır. Mersin balığından elde edilen havyar lüks tüketim malları arasında yer aldığından bu balık, diğer türlere göre daha önemlidir. En iyi havyar, Ekim ile Nisan ayları arasında yakalanan balıklardan elde edilir. Balıklar tuzlanıp ya da sade bir şeklide kurutularak havyar gibi satılmak üzere yakınlardaki pazarlara götürülür. ${ }^{158}$

Taman, Kuban Boyunun ticaret merkezlerinden birisidir. Bölge sakinleri ürünlerini satmak için bu kasabaya getirirler. Bu ürünler canlı hayvan ve hayvansal ürünler, bal, balmumu, kürk, yün, köle,

152 P. Minas Bıjışkyan, Karadeniz Kıyıları Tarih ve Coğrafyası, Terc. Hrand D. Andreasyan, İstanbul 1969, s. 89; BOA. MD. 114, h. 696; BOA. MD. 114/1, h. 522.

${ }^{153}$ BOA. MD. 147, h. 1165.

${ }^{154}$ Yücel Öztürk, "Osmanlı Karadenizi...", s. 87.

${ }^{155}$ Evliya Çelebi, a.g.e., s. 22; Velyaminov-Zernov, a.g.e., 747.

${ }^{156}$ Kornrumpf, a.g.m., s. 258.

15721 Mayıs 1864 'te Ruslar tarafından göçe zorlanan Çerkezler, Karadeniz'i gemilerle aşmaya çalışırken batan gemiler yüzünden çok sayıda kayıp vermişlerdir. Bu hadise göç etmek zorunda kalan Çerkezlerin hafızalarında kara bir hatıra olarak kalmıştır. "Çerkez yaşlıları, 'balıkların atalarını yediklerini, balık yemeleri halinde kendi atalarını yiyeceklerini' düşünerek, balık yemeyi" reddetmektedirler. Bu hadise Çerkezler arasında -en azında Anadolu'ya göç edenler arasında- balık tüketimini azaltmış olmalıdır. Levent Kazak, "Çerkes Soykırımı, Babaannem ve Sochi", http://www.radikal.com.tr/yorum/cerkes-soykirimi-babaannem-ve-sochi-1176669/, Erişim Tarihi 26.04.17.

${ }^{158}$ Jean Chardin, a.g.e., s. 98, 99; Tavernier, a.g.e., s. 326; Kornrumpf, a.g.m., s. 258; Malte Brun, a.g.e., s. 46.

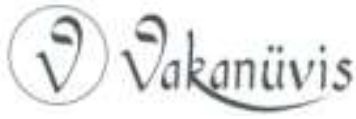


kurutulmuş balık ve havyardır. ${ }^{159}$ Yağ ticareti Taman ile özdeşleşmiş gibi görünmektedir. ${ }^{160}$ Özellikle "say yağı" ve tereyağı burada oldukça bol miktarlarda bulunmaktadır. Yağ ticareti Taman'ın "Kafir Bazarı" denilen varoşunda yapılmaktadır. XVII. yüzyılın ortalarında burada 150 kadar dükkan mevcuttur. ${ }^{161} 1732$ yılında İstanbul'dan Taman muhafızına gönderilen bir emir Taman'daki yağ ticaretinin boyutunu ve Taman'ın İstanbul'un yağ ihtiyacını karşılamadaki rolünü izah etmesi açısından önemlidir. Emirde İstanbul'da baş gösteren yağ kıtlığından bahsedilmekte ve bu sorunun çözümü için Taman yağlarının İstanbul'a gönderilmesi istenmektedir. Ancak Taman Muhafızı bu sıkıntılı zamanda yüksek kazanç sağlamak için yağ tüccarlarından fazla ücret talep etmiştir. Bunun üzerine tüccarlar yağı göndermekten vazgeçmişlerdir. Söz konusu yağ 1.500 'den fazla “berik ${ }^{162}$ yağı"dır. ${ }^{163}$

Taman, aynı zamanda Çerkez, Abaza ve Nogay topraklarına gitmek isteyen tüccarların konakladığı bir yerdir. ${ }^{164} 1706$ yılında İstanbul'dan Yenikale Muhafızına ve Taman Kadısına gönderilen bir emir, XVIII. yüzyılın başlarında Taman'daki ticari hayatın büyük bir canlılık kazandığına işaret etmektedir. Söz konusu belgede, Taman'ın Osmanlı egemenliğine girdiğinden beri Taman'daki ticaretin kale içinde yapıldığı, ancak bazı tüccarların kale dışında mallarını sattıkları ve bundan dolayı kale içindeki tüccarların mağdur oldukları belirtilmekte, ticaretin yine eskiden olduğu gibi kale içinde yapılmasının gerektiği anlatılmaktadır. ${ }^{165}$ Bu durum önemli bir ticaret merkezi olan Azak'ın Rusların eline geçmesiyle alakalı olabilir. ${ }^{166}$ Osmanlı Devleti, Azak'ı kaybedince burayla yapılan ticarete sıkı bir denetim getirmiştir. ${ }^{167}$

\footnotetext{
${ }^{159}$ Reineggs, a.g.e., s. 289; Jean Chardin, a.g.e., s. 106; Malte Brun, a.g.e., s. 47.

${ }^{160}$ Ahmed Cavid Bey, a.g.e., s. 269; Evliya Çelebi, a.g.e., s. 268.

${ }^{161}$ Evliya Çelebi, a.g.e., s. 267; Kornrumpf, a.g.m., s. 249.

162 Berik, yağların muhafaza edildiği büyük ve küçük tulumlardır. (BOA. MD. 138, s. 809)

${ }^{163}$ BOA. MD. 143, h. 134.

${ }^{164}$ Kornrumpf, a.g.m., s. 249; Özdem, a.g.e., s. 163; Kırım Hanlarına Nâme-i Hümâyûn (2 Numaralı Name Defteri), s. 179.

${ }^{165}$ BOA. MD. 115, h. 1374.

${ }^{166}$ Bkz. M. Cavid Baysun, "Azak”, iA., C. 2, İstanbul 1979, s. 85 vd.; Akdes Nimet Kurat, Rusya Tarihi: Başlangıçtan 1917'ye Kadar, Ankara 1987, s. 253, 255.

${ }^{167}$ BOA. MD. 115, h. 2059.
} 
Böylelikle tüccarlar Azak yerine Taman'a yönelmiş ve Taman'da yapılan ticaret kale içine sığamayacak kadar artmış gibi görünmektedir.

Deri, havyar, bal, at ve köle satışının yapıldığı Temrük, bölgenin bir diğer önemli ticaret merkezidir. ${ }^{168}$ XVI. yüzyılda Temrük'ün oldukça hareketli bir limanı bulunmaktadır. Her yıl, limana yanaşan çok sayıda gemi Temrük havyarını ve tuzlanmış balığını İstanbul'a taşımaktadır. ${ }^{169}$ $\mathrm{Bu}$ işten elde edilen gelirler ise İstanbul ve Bahçesaray arasında paylaşılmaktadır. ${ }^{170}$ XVII. yüzyılda Kuban Nehri'nin taşıdığı alüvyonlar kentin limanına girişi sağlayan Yeleşke Boğazını kapatmaya başlayınca liman da canlılığını kaybetmiştir. ${ }^{171}$ Bu durum kentteki ticari hayatı olumsuz etkilemiş olabilir. Bununla birlikte limandaki hareketlilik yerini karayollarındaki hareketliliğe bırakmıştır. Bir Osmanlı devlet görevlisi olan Mustafa Atıf tarafından hazırlanmış 1740/1741 tarihli rapor bu durumu teyit eder niteliktedir. Raporda, Temrük'e her yıl on bin kadar arabanın gelme ihtimalinin bulunduğu ifade edilmektedir. Ayrıca raporda Temrük'e han ve nureddin ${ }^{172}$ adına görevliler tayin edilmesi ve her arabadan ve esir satışından bir guruştan iki guruşa kadar vergi alınması tavsiye edilmektedir. ${ }^{173}$ Burada anlatılanlar ve tavsiye edilenler Temrük'teki ticari hayatın canlılığına dair bir delil oluşturmaktadır.

Taman ve Temrük'ün Osmanlı Devleti ve Kırım Hanlığındaki köle ticaretinde ayrı bir yeri vardır. ${ }^{174}$ Taman ve Temrük, Çerkezlerin ve

\footnotetext{
${ }^{168}$ A. De La Motraye, a.g.e., s. 40.

${ }^{169}$ Evliya Çelebi, a.g.e., s. 268.

170 A. De La Motraye, a.g.e., s. 40. Gümrük teşkilatının olmadığı yerlerde ticaret gemilerinden alınan vergilerin bir kısmı bölge beylerine aktarılmakta, diğer kısmı ise bölgenin imarına harcanmaktadır. (Sadık Müfit Bilge, "15.-18. Yüzyıllarda İstanbul ve Kafkasya İskeleleri Arasında Deniz Ticareti: Tâcirler, Gemiciler, Köylüler", III. Uluslararası Osmanlı İstanbulu Sempozyumu, Bildirileri 25-26 Mayıs 2015, Ed. Feridun Emecan vd., İstanbul 2015, s. 66)

${ }^{171}$ Evliya Çelebi, a.g.e., s. 268.

${ }^{172}$ Nureddinlik Kırım Hanlığında ikinci veliahda verilen idari bir payedir.

173 Öztürk, "Osmanlı Karadenizi...", s. 86-87.

${ }^{174}$ Karadeniz'deki köle ticareti için bkz. Alan Fisher, "Muscovy and the Black Sea Slave Trade", A Precarious Balance: Conflict, Trade and Diplomacy on the Russian-Ottoman Frontier, İstanbul 1999; Alan Fisher, "The Sale of Slaves in the Ottoman Empire: Markets and State Taxes on Slave Sales. Some Prelimanry Considerations", A Precarious Balance: Conflict, Trade and Diplomacy on the Russian-Ottoman Frontier,
}

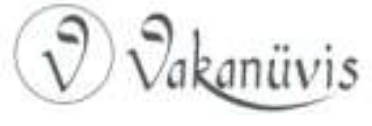


Nogayların akınlarda ele geçirdikleri köleleri sattıkları yerlerdendir. Bu kentlerdeki köle ticaretinin önemi, bu merkezlerde sadece köle ticareti ile uğraşan bir tacir zümresinin mevcudiyetinden ve bölge yöneticilerinin zaman zaman bu tacirler ile ortaklaşa hareket edip kanunlara aykırı davranışlarda bulunmalarından anlaşılmaktadır. ${ }^{175}$

Taman ve Temrük dışında Acu, Soğucak, Kızıltaş ve Anapa gibi yerlerde de ticaretin yapıldığı söylenebilir. Ayrıca bazı yerlerde kısa süreli kurulan pazarlar bulunmaktadır. Çerkezlerin Kavak isimli kasabasında kurulan köle pazarı ile Âdemî Çerkezlerinin topraklarında kurulan panayır buna örnek olarak gösterilebilir. ${ }^{176}$

Kuban Boyunda iki ana ticaret yolu bulunmaktadır. Bunlardan birisi doğu-batı istikametinde ilerlemekte ve Kuban Nehri'ni takip etmektedir. Bu yol üzerinde Anadolu ya da Rumeli'deki gibi hanlar mevcut değildir. Bu yüzden tüccarlar güvenliklerini sağlayabilmek için büyük gruplar halinde hareket etmek zorundadırlar. 1722'de Kefe, Karasu ve Taman tacirlerinden oluşan 54 arabalık bir kervanın, Topal İvan'ın idaresindeki bir Kazak-Kalmuk eşkıya zümresinin saldırısına uğraması, kalabalık kervanların bile bazen saldırılardan kurtulamadığını göstermektedir. ${ }^{177}$

İkinci ana ticaret yolu ise kuzey-güney doğrultusunda ilerlemekte ve bölgenin batısındaki denizlerden geçmektedir. Bu yolun Karadeniz'de kalan kısmı için aniden patlayan fırtınalar, Azak Denizi kısmında ise denizin sığlığı ticaret gemileri için büyük tehlike oluşturmaktadır. Ayrıca 25 Kasım'da başlayan ve 21 Mart'a kadar süren kış ayında Karadeniz'de ve Azak Denizinde yol almak neredeyse imkansızdır. Bu

İstanbul 1999; Alan Fisher, "Chattel Slavery in the Ottoman Empire", A Precarious Balance: Conflict, Trade and Diplomacy on the Russian-Ottoman Frontier, İstanbul 1999; Zübeyde Güneş Yağcı, "16. Yüzyılda Kırım'da Köle Ticareti”, Karadeniz Araştırmaları, S. 8, 2005; Zübeyde Güneş Yağcı, "İstanbul Gümrük Defterine Göre Karadeniz Köle Ticareti (1606-1607), History Studies, Vol. 3/2, 2011; Ensar Köse, "Kefe Limanı ve Karadeniz Ticareti (18. Yüzyılın İlk Yarısı)", Ordu Üniversitesi Sosyal Bilimler Araştırma Dergisi, 2014; Bilge, a.g.m., s. 88 vd.

${ }^{175}$ BOA. MD. 115, h. 2831.

${ }^{176}$ Âşılk Mehmed, a.g.e., s. 1101; Evliya Çelebi, a.g.e., s. 281, 282.

${ }^{177}$ BOA. MD. 130, s. 1240; Subhî Mehmed Efendi, a.g.e., s. 283.

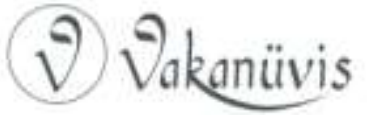


yüzden bu aylar arasında deniz yolu etkinliğini yitirir. ${ }^{178} \mathrm{Bu}$ gibi durumlarda denize paralel olarak seyreden karayollarının önemi artmaktadır. ${ }^{179}$ Bu yollar, yol üzerlerinde inşa edilmiş kaleler tarafından korunduğundan Kuban Nehri'ni takip eden yola göre daha güvenlidirler. ${ }^{180}$

\section{Sonuç}

Kuban Boyu, Osmanlı Devleti'nin egemenliği altında olmakla birlikte bölgedeki siyasi yaşamın belirleyicisi Kırım Hanlığı gibi görünmektedir. Kırım Hanlığı için bölgenin itaat altında tutulması hanlığın bölgeye yönelik politikasının ana ilkesini oluşturur. Bu ana ilkenin uygulanışı bölgedeki etnik gruplara ya da iktisadi ve siyasi koşullara göre değişebilmektedir. Öte yandan hanların, Kırım Hanlığının buhranlı dönemlerinde bu politika ile çelişebilen uygulamaları yürürlüğe koydukları görülmüştür. Bu durum sadece Kırım Hanlığının değil aynı zamanda Osmanlı Devletinin de bölgedeki otoritesinin sarsılmasına yol açmıştır.

Osmanlı Devleti'nin daha çok Kuban Boyunun batısında kalan bazı yerlerin idaresiyle ilgilendiği, bunun dışında bölgenin geri kalanı için mevcut siyasi yapıyı koruyan bir politika benimsediği söylenebilir. Batıdaki yerlerle ilgilenmesi, bu yerlerin Karadeniz'in güvenliği açısından önem arz etmesinden ve sahip olduğu ulaşım imkanlarından dolayı birer antrepo özelliği taşımasından ileri gelmiştir.

Rusların Kafkasları ele geçirmeye yönelik politikası bölgedeki siyasi ve iktisadi istikrara zarar vermiştir. Bununla birlikte bu politika bölgenin etnik haritasının şekillenmesinde ve bölgedeki etnik grupların bir bütün halinde hareket etmesine büyük katkı sağlamıştır. Bu durum Rusların bölgedeki ilerleyişini zorlaştıran bir etken olarak değerlendirilebilir.

Çerkezler, Nogaylar ve Kazaklar bölgede ön plana çıkan etnik gruplardır. Çerkezler bölgenin en eski sakinleridirler. Nogaylar ve Kazaklar ise bölgeye sonradan yerleşmişlerdir. Bu durum bölgede etnik

\footnotetext{
${ }^{178}$ Bilge, a.g.m., s. 57; Bıjışkyan, a.g.e., s. 89; A. De La Motraye, a.g.e., s. 40; Öztürk, "Osmanlı Karadenizi...", s. 84.

${ }^{179}$ Kornrumpf, a.g.m., s. 250.

${ }^{180}$ BOA. MD. 114, h. 277; BOA. MD. 115, h. 2059.
} 
bir çatışmaya yol açmamış, bilakis etnik gruplar arasında bir uyumu beraberinde getirmiştir. Bunda Osmanlı Devleti'nin, Kırım Hanlığının ve Rusya'nın bölgeye yönelik politikaları etkili olmuştur. Buna ilaveten benzer iktisadi faaliyetlerin etnik gruplar arasındaki uyuma katkı sağladığı söylenebilir.

Bölge ekonomisinin temeli hayvancılık, tarım ve avcılığa dayanır. Tarım dışındaki faaliyetlerin göçebelerin geleneksel uğraşları olduğu bilinmektedir. Bu noktada bölgede göçebelerin yoğun olduğu ya da göçebe iktisadi zihniyetinin egemen olduğu söylenebilir. Bölgede tarımın ikinci planda kalmasında bu anlayışın önemli bir payı bulunmaktadır. Bununla birlikte tarımın göçebeler arasında da yer edindiğini belirtmek gerekir.

Bölgenin batısında bulunan ticaret merkezleri, mallarını satmak ya da gündelik hayatta ihtiyaç duydukları sanayi ürünlerini almak için Çerkezler, Nogaylar ve Kazaklar tarafından sık sık ziyaret edilmektedir. Dolayısıyla bu ticaret merkezleri hem bölge sakinlerinin dışarıya açılan kapıları olmuş hem de bölgenin siyasal bütünlüğünün sağlanmasına görece yardım etmiştir.

\section{Kaynakça}

\section{Başbakanlık Osmanlı Arşivi (BOA)}

Mühimme Defteri $(M D)$ : nr. 110, 114, 114/1, 115, 122 130, 131, 133, 134, 138, 142, 143, 147, 153, 155.

\section{Kaynak Eserler}

A. De La Motraye, A. De La Motraye's Travels through Europe, Asia and into Part of Africa, V. II, London 1730.

Ahmed Cavid Bey, Osmanlı Rus ilişskileri Tarihi, Haz. Adnan Baycar, İstanbul 2004.

Âşık Mehmed, Menâzırü'I-Avâlim, C. III, Haz. Mahmut Ak, Ankara 2007.

Baron de Tott, Türkler ve Tatarlara Dair Hâtıralar, Çev. Mehmet R. Uzmen, İstanbul ts.

Defterdar Sarı Mehmed Paşa, Zübde-i Vekayiât, Haz. Abdülkadir Özcan, Ankara 1995.

Edmund Spencer, Türkiye, Rusya, Karadeniz ve Çerkezistan, Çev. Dilek Cenkçiler, Ankara 2014.

Evliya Çelebi, Evliya Çelebi Seyahatnâmesi, C. VII, Haz. Yücel Dağlı-Seyit Ali Kahraman-Robert Kahraman, İstanbul 2003. 
George Ellis, Memoir of a Map of the Countries Comprehended between the Black Sea and Caspian with an Account of the Caucasian Nations, London 1788.

Hezarfen Hüseyin Efendi, Telhîsü'l-Beyân Fî Kavânîn-i Âli-i Osman, Haz. Sevim ilgürel, Ankara 1998.

Jan Janszoon Struys, The Perillous and Most Unhappy Voyages of John Struys through Italy, Greece, Lifeland, Muscovia, Tartary, Media, Persia, EastIndia, Japan, and other Places in Europe, Africa and Asia, London 1694, https://quod.lib.umich.edu/e/eebo/A61855.0001.001/1:9.5?rgn=div2;view=f ulltext;q1=adam+olearius, Erişim Tarihi: 08.04.2017.

Jean-Baptiste Tavernier, Tavernier Seyahatnamesi, Çev. Teoman Tunçdoğan, İstanbul 2006.

Jean Chardin, Chardin Seyahatnamesi, Çev. Ayşe Meral, Ed. Stefanos Yerasimos, İstanbul 2014.

Julius von Klaproth, Travels in the Caucasus and Georgia, London 1814.

Kırım Hanlarına Nâme-i Hümâyûn (2 Numaralı Name Defteri), Haz. Murat Cebecioğlu vd., İstanbul 2013.

Kornrumpf, Hans-Jürgen, "Südrussland und die Krım um 1740", Osmanlı Araştırmaları IX, İstanbul 1989, s. 235-261.

Moritz Wagner, Kafkas Rus Savaşı'nda Çerkesler-Çeçenler-Kazaklar ve Gürcüler, Çev. Sedat Özden, İstanbul 1999.

Mustafa Kesbî, ibretnümâ-yı Devlet, Haz. Ahmet Öğreten, Ankara 2002.

P. S. Pallas, Travels through The Russian Empire in the Years 1793 and 1794, Vol. II, London 1812.

Râşid Mehmed Efendi-Çelebizâde İsmâil Âsım Efendi, Târîh-i Râşid ve Zeyli, Haz. Abdülkadir Özcan vd., C. I, İstanbul 2013.

Râşid Mehmed Efendi-Çelebizâde İsmâil Âsım Efendi, Târîh-i Râşid ve Zeyli, Haz. Abdülkadir Özcan vd., C. III, İstanbul 2013.

Reineggs and Marshal Bieberstein, A General, Historical and Topographical Description of Mount Caucasus, V. I, Translated Charles Wilkinson, London 1807.

Saîd Giray, Târîh-i Saîd Giray Hân, staatsbibliothek zu Berlin, Osmanische Sammelhandschrift, Hs. Or. 923.

Seyyid Muhammed Rıza, Es-Sebü's-Seyyâr Fî Ahbâr-ı Mülûku't-Tatar, Haz. Mirza Kazım Bek, Kazan 1832.

Silâhdar Fındıklılı Mehmed Ağa, Nusretnâme, Sadeleştiren İsmet Parmaksızoğlu, C. I/II, İstanbul 1963.

Silâhdar Fındıklılı Mehmed Ağa, Nusretnâme, Sadeleştiren İsmet Parmaksızoğlu, C. II/II, İstanbul 1969.

Subhî Mehmed Efendi, Subhî Tarihi, Haz. Mesut Aydıner, İstanbul 2007. 
Şem'dânî-zâde Fındıklılı Süleyman Efendi, Mür'i't Tevârih, C. I, Haz. Münir Aktepe, İstanbul 1976.

W. Eton, A Survey of the Turkish Empire in which are Considered, London 1799.

Xavier Hommaire de Hell, Travels in the Steppes of the Caspian Sea, The Crimea, The Caucasus, London 1847.

V. V. Velyaminov-Zernov, Kırım Yurtına ve Ol Taraflarga Dair Bolgan Yarlıglar ve Hatlar, Haz. Melek Özyetgin-ilyas Kamalov, Ankara 2009.

\section{Tetkik Eserler}

Adiloğlu, Adilhan, Karaçay-Malkar Türkleri, Ankara 2005.

Alpargu, Mehmet, Nogaylar, İstanbul 2007.

Bala, Mirza, "Çerkesler", IA, C. 3, İstanbul 1995, s. 375-386.

Barrett, Thomas M., At The Edge of Empire: The Cossacks and the North Caucasus Frontier, 1700-1860, Colorado 1999.

Barut, Ali, "Kırım Hanlığı ile Kuzey Batı Kafkasya Iilişkilerinde Atalık Müessesesinin Yeri" Emel, S. 217, 1997, s. 21-24.

Basmacı, Yakup, "Kafkasya Bölgesi Su Kaynakları", Yeni Türkiye (Kafkaslar Özel Sayısı), S. 71, C. I, 2015, s. 326-339.

Başer, Alper, "Evliya Çelebi Seyahatnamesi'nde Nogaylar", Türk Dünyası incelemeleri Dergisi, XI/2, 2011, s. 117-128.

Başer, Alper, "Kırım Hanlığı Tarihinde Mangıt Kabilesi", Doğu Avrupa Türk Mirasının Son Kalesi Kırım, İstanbul 2015, ss. 75-98.

Bayramaliyev, Osman, "Rus tarihçi Sen, Don kozakları ile Kırım Hanlığı arasındaki gerçek ilişkileri anlatacak", 18 Temmuz 2011, http://qha.com.ua/tr/savas-guvenlik/rus-tarihci-sen-don-kozaklari-ile-kirimhanligi-arasindaki-gercek-iliskileri-anlatacak/96625/, Erişim Tarihi 22.04.2017.

Baysun, M. Cavid, “Azak”, iA., C. 2, İstanbul 1979, s. 85-89.

Berber, Oktay, "Kafkasya'da Moğol Kökenli Bir Halk: Kalmuklar", Yeni Türkiye (Kafkaslar Özel Sayısı), S. 71, C. II, s. 363-377.

Berje, Adolf, Kafkasyalı Dağlı Kavimlerin Kısa Tasvirleri, Çev. Murat Papşu, Ankara 1999.

Bıyık, Ömer, Kırım'ın Idarî ve Sosyo-Ekonomik Tarihi, İstanbul 2014.

Bilge, Sadık Müfit, Osmanlı Çağı'nda Kafkasya, İstanbul 2012.

Bilge, Sadık Müfit, “15.-18. Yüzyıllarda İstanbul ve Kafkasya İskeleleri Arasında Deniz Ticareti: Tâcirler, Gemiciler, Köylüler", III. Uluslararası Osmanlı Istanbulu Sempozyumu, Bildirileri 25-26 Mayıs 2015, Ed. Feridun Emecan vd., İstanbul 2015, s. 53-90.

Bıjışkyan, P. Minas, Karadeniz Kıyıları Tarih ve Coğrafyası, Terc. Hrand D. Andreasyan, İstanbul 1969.

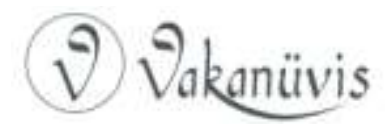


Boeck, Brian J., Imperial Boundaries Cossacks Communities and EmpireBuilding in the Age of Peter the Great, New York 2009.

Budak, Mustafa, "Rusya'nın Kafkasya'da Yayılma Siyaseti”, Türkler, C. 18, Ankara 2002, ss. 488-515.

Bülbül, İsmail, Başlangıcından Rus Hakimiyetine Kadar Kumuk Türkleri ve Tarku Şamhallığı, Basılmamış Doktora Tezi, Sakarya 2011.

Bülbül, İsmail, "Yedisan-Bucak Nogaylarının 1756 ve 1758 İsyanları”, Türk Tarihi Araştırmaları Dergisi, Yıl 1, Sayı 1, 2016, s. 74-113.

Derin, Derya, Abdülgaffar Kırımî'nin Umdet'ül-Ahbar'ına (Umdet'ütTevarih) Göre Kırım Tarihi, Basılmamış Yüksek Lisans Tezi, Ankara 2003.

Derin Paşaoğlu, Derya, "Altın Orda ve Kırım Sahasında Bozkır Aristokrasisinin Güçlü Temsilcileri: Emir Rektemür ve Şirin Mirzalar”, Ankara Üniversitesi Dil ve Tarih-Coğrafya Fakültesi Tarih Bölümü Tarih Araştırmaları Dergisi, C. 33, 2014, s. 147-190.

Eravcı, H. Mustafa, "Selim Giray", DiA, C.36, 2009, s. 428-429.

Enisimof, Sergey, Kafkas Kılavuzu, Çev. Binbaşı Sadık, İstanbul 1926.

Fisher, Alan, Kırım Tatarları, İstanbul 2009.

Fisher, Alan, "Muscovy and the Black Sea Slave Trade", A Precarious Balance: Conflict, Trade and Diplomacy on the Russian-Ottoman Frontier, İstanbul 1999, s. 27-46.

Fisher, Alan, "The Sale of Slaves in the Ottoman Empire: Markets and State Taxes on Slave Sales. Some Prelimanry Considerations", A Precarious Balance: Conflict, Trade and Diplomacy on the Russian-Ottoman Frontier, İstanbul 1999, s. 77-104.

Fisher, Alan, "Chattel Slavery in the Ottoman Empire", A Precarious Balance: Conflict, Trade and Diplomacy on the Russian-Ottoman Frontier, İstanbul 1999, s. 105-128.

Grigoriantz, Alexandre, Kafkasya Halkları, İstanbul 1999.

Güneş Yağcı, Zübeyde, "16. Yüzyılda Kırım'da Köle Ticareti”, Karadeniz Araştırmaları, S. 8, 2005, s. 12-30.

Güneş Yağcı, Zübeyde, “Istanbul Gümrük Defterine Göre Karadeniz Köle Ticareti (1606-1607), History Studies, Vol. 3/2, 2011, s. 371-384.

Howorth, Henry H., History of the Mongols from the 9th to the 19th century, Part II, Division 1, London 1880.

Inalcık, Halil, "Kırım Hanlı̆̆ı", IA, C. 6, İstanbul 1977, s. 746-756.

İvanics, Maria, "Bozkırdaki Bir Kabilenin Kökeni ve Yükselişi: Şirinler”, Çev. Mustafa Işık, Doğu Avrupa Türk Mirasının Son Kalesi Kırım, İstanbul 2015, s. 53-68.

Joseph von Hammer, Kırım Hanlığı Tarihi, İstanbul 2013. 
Kazak, Levent, "Çerkes Soykırımı, Babaannem ve Sochi", http://www.radikal.com.tr/yorum/cerkes-soykirimi-babaannem-ve-sochi1176669/, Erişim Tarihi 26.04.17.

Khazanov, Anatoly M., Göçebe ve Dış Dünya, Çev. Ömer Suveren, İstanbul 2015.

Köse, Ensar, "Kefe Limanı ve Karadeniz Ticareti (18. Yüzyılın İlk Yarısı)", Ordu Üniversitesi Sosyal Bilimler Araştırma Dergisi, 2014, s. 24-56.

Kurat, Akdes Nimet, Altın Ordu, Kırım ve Türkistan Hanlarına Ait Yarlık ve Bitikler, İstanbul 1940.

Kurat, Akdes Nimet, Rusya Tarihi: Başlangıçtan 1917'ye Kadar, Ankara 1987.

Kurat, Akdes Nimet, IV-XVIII. Yüzyıllarda Karadeniz Kuzeyindeki Türk Kavimleri ve Devletleri, Ankara 1992.

Malte Brun, Universal Geography or a Description of all the Parts of the World, V. II, Boston 1824.

Mertayak, Aydın, Nişli Mehmed Ağa'nın Rusya Sefareti ve Sefaretnamesi (1722-1723), Basılmamış Yüksek Lisans Tezi, Tokat 2005.

Nevruz, Yılmaz, Umûmî Kafkas Tarihine Giriş, C. II, İstanbul 2016.

Özbek, Baturay, Çerkez Tarihi Kronolojisi, Ankara 1991.

Özdem, Zeynep, Kırım Karasubazar'da Sosyo-Ekonomik Hayat, Ankara 2010.

Öztürk, Yücel, "Osmanlı Karadenizi Hakkında Bir Risale”, Karadeniz Araştırmaları, S. 13 (Bahar 2007), s. 65-92.

Öztürk, Yücel, "Doğu Avrupa Türk Mirasının Son Kalesi: Kırım Hanlığı", Doğu Avrupa Türk Mirasının Son Kalesi Kırım, Ed. Yücel Öztürk, İstanbul 2015, s. 13-48.

Papşu, Murat, "Çerkezlerde Atçılık ve At Kültürü", Nart, S. 72, Mart-Nisan 2010, s. 52-56.

Smirnov, V. D., Osmanlı Dönemi Kırım Hanlığı, Çev. Ahsen Batur, İstanbul 2016.

Şen, Muhammet, Kırım Hanlığı'nda I. Selim Giray Han Dönemi (16711704), Basılmamış Doktora Tezi, İzmir 2013.

Tavkul, Ufuk, Kafkasya Gerçeği, İstanbul 2007.

Tavkul, Ufuk, "Kırım-Kafkasya İlişkilerinde 'Atalık' Kurumunun Kökeni Üzerine Değerlendirmeler”, Karadeniz Araştırmaları, S. 51, 2016, s. 223-232.

Uzunçarşılı, İsmail Hakkı, Osmanlı Tarihi, C. IV, II. Kısım, Ankara 1995.

Ürekli, Muzaffer, "Rus Yayılması Karşısında Kırım Hanlığı ve Kafkasya", Kafkasya Araştırmaları I, İstanbul 1988, s. 12-24. 
EK-1

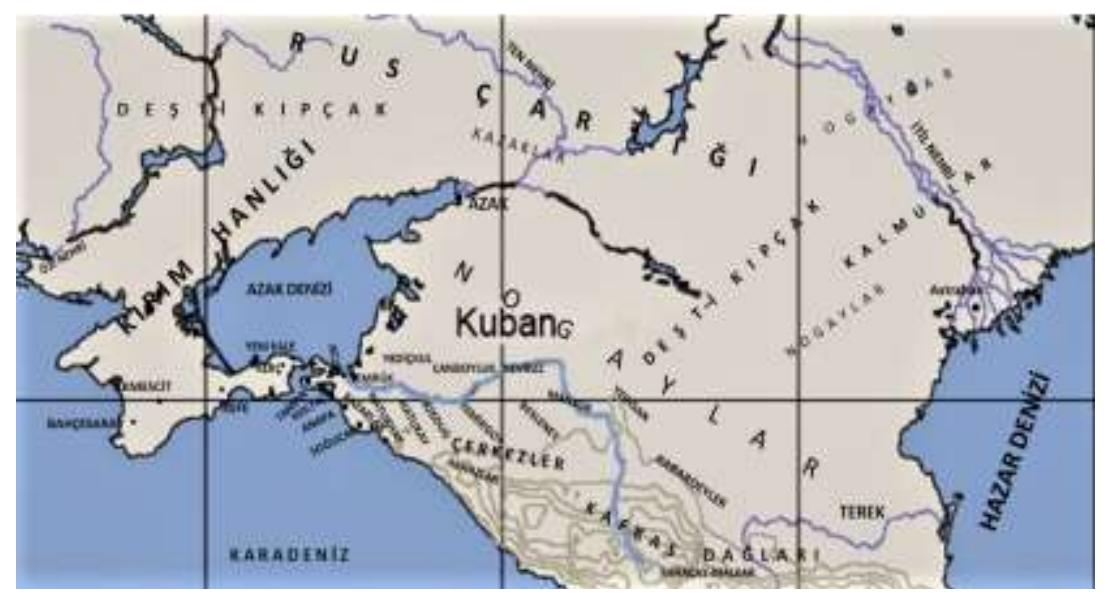

(XVIII. Yüzyılın Illk Yarısında Kuban Boyu) 